\title{
Design, Synthesis, and Molecular Docking Studies of a Conjugated Thiadiazole-Thiourea Scaffold as Antituberculosis Agents
}

\author{
Esra Tatar, ${ }^{a}$ Sevgi Karakuş, ${ }^{a}$ Şükriye Güniz Küçükgüzel, ${ }^{a}$ Sinem Öktem Okullu, ${ }^{b}$ Nihan Ünübol, ${ }^{b}$ \\ Tanıl Kocagöz, ${ }^{b}$ Erik De Clercq, ${ }^{c}$ Graciela Andrei, ${ }^{c}$ Robert Snoeck,${ }^{c}$ Christophe Pannecouque, \\ Sadık Kalayc1, ${ }^{d}$ Fikrettin Şahin, ${ }^{d}$ Dharmarajan Sriram, ${ }^{e}$ Perumal Yogeeswari, ${ }^{e}$ and \\ İlkay Küçükgüzel*,a
}

${ }^{a}$ Department of Pharmaceutical Chemistry, Faculty of Pharmacy, Marmara University; Haydarpaşa, Istanbul 34668, Turkey: ${ }^{b}$ Department of Medical Microbiology, School of Medicine, Actbadem University; Ataşehir, İstanbul 34752, Turkey: ' Rega Institute for Medical Research; KU Leuven, Leuven, Minderbroedersstraat 10, B-3000 Leuven, Belgium: ${ }^{d}$ Department of Genetics and Bioengineering, Faculty of Engineering and Architecture, Yeditepe University; Istanbul 34755, Turkey: and ${ }^{e}$ Medicinal Chemistry and Drug Discovery Research Laboratory, Pharmacy Group, Birla Institute of Technology and Science-Pilani; Hyderabad Campus, Jawahar Nagar, Telangana 500078, India.

Received September 8, 2015; accepted December 16, 2015

In view of the emergence and frequency of multidrug-resistant and extensively drug-resistant tuberculosis and consequences of acquired resistance to clinically used drugs, we undertook the design and synthesis of novel prototypes that possess the advantage of the two pharmacophores of thiourea and 1,3,4-thiadiazole in a single molecular backbone. Three compounds from our series were distinguished from the others by their promising activity profiles against Mycobacterium tuberculosis strain $\mathbf{H}_{37} R$. Compounds 11 and 19 were the most active representatives with minimum inhibitory concentration (MIC) values of 10.96 and $11.48 \mu \mathrm{M}$, respectively. Compound 15 was shown to inhibit $M$. tuberculosis strain $\mathrm{H}_{37} \mathrm{Rv}$ with an MIC value of $17.81 \mu$ м. Cytotoxicity results in the Vero cell line showed that these three derivatives had selectivity indices between 1.8 and 8.7. In order to rationalize the biological results of our compounds, molecular docking studies with the enoyl acyl carrier protein reductase (InhA) of M. tuberculosis were performed and compounds 11,15 , and 19 were found to have good docking scores in the range of -7.12 to $-7.83 \mathrm{kcal} / \mathrm{mol}$.

Key words 1,3,4-thiadiazole; thiourea; antituberculosis activity; cytotoxicity; molecular docking

Tuberculosis has been a well known infection throughout known history of humankind and was called "Captain Among These Men of Death" in 18th and 19th centuries. From 1882, the date when Mycobacterium tuberculosis was identified as the etiological agent of tuberculosis, till now scientists have struggled to discover efficient therapies against this contemporary infection. ${ }^{1)}$ Approximately twenty years after WHO declared tuberculosis (TB) a "global public health emergency," an estimated 8.6 million new case and 1.3 million death were noted in WHO's Global Tuberculosis Report 2013.2) These large numbers of cases and deaths were based upon decreasing efficacy of four first line drugs; isoniazid, rifampicin, ethambutol, pyrazinamide and increasing resistance to at least isoniazid and rifampicin which was called multidrugresistant (MDR) tuberculosis (TB) MDR-TB treatment comprises of second line antituberculosis drugs; ethionamide, prothionamide, thioacetazone, isoxyl (thiocarlide), amikacin, kanamycin or capreomycin as well as fluoroquinolone derivatives (ofloxacin, levofloxacin, moxifloxacin and gatifloxacin). Second line antituberculosis drugs are less potent, more toxic and more expensive than the first line drugs moreover antiTB injectable drugs; amikacin, kanamycin or capreomycin decreases the therapy success rate due to their route of administration. ${ }^{3)}$

As a consequence of multiple mutations in specific resistant-associated genes of Mycobacterium tuberculosis (inhA, $k a t G, r p o B, g y r A, r r s, t l y A$ and eis), extensively drug-resistant (XDR) TB has arisen. It was shown that treatment of XDR-TB by using isoniazid and rifampicin plus a fluoroquinolone de- rivative and amikacin, kanamycin or capreomycin is ineffectual. ${ }^{4)}$ In view of the frequency and emergence of MDR and XDR tuberculosis and consequences of acquired resistance to clinically employed drugs, researchers have persisted in performing synthesis and anti-tuberculosis evaluation of novel compounds bearing various chemical entities.

Compounds with thiourea, acylthiourea and thioamide moiety have been synthesized as a result of drawing inspiration from second line antituberculosis pro-drugs; ethionamide (ETH), prothionamide, thiacetazone and isoxyl (thiocarlide). ${ }^{5-11)}$ It was already known that, ETH inhibits cell wall biosynthesis of $M$. tuberculosis. Baulard et al. reported the identification of ETH-activator; Rv3854c which was then termed EthA. ${ }^{12)}$ Another noteworthy work, revealed the mechanism of activation of ETH due to corresponding $S$ oxide by monooxygenase Rv3854c. ${ }^{13)}$ It was noted that isoxyl activation also requires EthA-mediated oxidation. ${ }^{14)}$ Isoxyl has been reported to be non-toxic in isoxyl-treated individulas at therapeutic doses but its poor solubility in water decreases its bioavalibility henceforth a new administration route-direct pulmonary delivery has been suggested due to refurbishment of old agents for emerging clinical needs. ${ }^{15)}$ All of these phenomenon maintain undivided interest in thiourea synthesis. As well as thiourea based compounds, new candidates bearing both heterocycles and thiourea moieties have been shown as promising antituberculosis agents. ${ }^{7,8,10,16)}$ It is known that heterocyclic scaffolds possess a leading role in designing novel class of chemotypes as drug candidates. Among them, 1,3,4-thiadiazoles have been reported to possess a wide 
<smiles>CC(=O)Nc1nnc(S(N)(=O)=O)s1</smiles>

Acetazolamide<smiles>Cc1nnc(NS(=O)(=O)c2ccc(N)cc2)s1</smiles>

Sulfamethizole<smiles>CC(=O)/N=c1/sc(S(N)(=O)=O)nn1C</smiles>

Methazolamide<smiles>Cn1c([N+](=O)[O-])cnc1-c1nnc(N)s1</smiles>

Megazol<smiles>Cc1nnc(SCC2=C(C(=O)O)N3C(=O)[C@@H](NC(=O)Cn4cnnn4)[C@H]3SC2)s1</smiles>

Cefazolin

Fig. 1. Several Drugs on Market Possessing 1,3,4-Thiadiazole Core

range of biological activities including antiproliferative, antibacterial, antifungal, and antimycobacterial functions. ${ }^{17-21)}$ Based on reported antitumor and uricogenic activity of 2-amino-1,3,4-thiadiazole (ATDA, NSC4728); Abdel Rahman and Mohamed $^{22)}$ synthesized 1,3-disubstituted thioureas via 5-(4-bromophenyl)-1,3,4-thiadiazol-2-amine. Some analogues from this series, that unite 1,3,4-thiadiazol ring with thiourea moiety, were reported to demonstrate promising $\mathrm{IC}_{50}$ values (2.58-6.47 $\mu \mathrm{m})$ against A549 (Non-small Cell Lung Cancer) cell line. ${ }^{22}$ Another work on very similar chemotypes with our compounds has reported the synthesis of triazolothiadiazolethiones and thiadiazolothiadiazolimines that were gained by heterocyclization of $N$-(4-chlorophenyl)/phenyl- $N N^{\prime}-[5-(4-$ methoxyphenyl)/(2-chlorophenyl)/phenyl-1,3,4-thiadiazol-2-yl]thioureas and $N$-phenyl/(2-chlorophenyl)- $N$ '-(5-phenyl-1,3,4thiadiazol-2-yl)thioureas as well as their antifungal activity against Aspergillus niger and Fusarium oxysporium. ${ }^{23)}$

Actually, 1,3,4-thiadiazole ring is found in several drugs in clinical use. Typical examples are Acetazolamide and Methazolamide (carbonic anhydrase inhibitors); Sulfamethizole and Cefazolin (antibacterials) and Megazol (treatment of human African trypanosomiasis) (Fig. 1). We have recently reported two groups of novel 1,3,4-thiadiazole-4-thiazolidinone hybrids which were active against hepatitis $\mathrm{C}$ virus (HCV) via inhibition of NS5B polymerase. ${ }^{24,25)}$ It is also worth to mention that $M$. tuberculosis contains three $\beta$-carbonic anhydrase (CA) genes in its genome; Rv1284, Rv3588c and Rv3273 encoding for $\mathrm{mtCA} 1, \mathrm{mtCA} 2$ and $\mathrm{mtCA} 3$, respectively. Inhibitory activity of acetazolamide and methazolamide against mtCA 1 and mtCA 3, with inhibition constants in the submicromolar ranges has been reported. ${ }^{26)}$ This promising result may lead to the refurbishment of old carbonic anhydrase inhibitors as new antimycobacterials.

In 2011, GlaxoSmithKline has reported a 1,3,4-thiadiazole derivative containing pyrazole and thiazole linkages. This scaffold [A] has been reported to show potent activity towards Mtb (minimum inhibitory concentration $(\mathrm{MIC})=0.19 \mu \mathrm{M})$ via potent enoyl acyl carrier protein reductase (InhA) inhibition $\left(\mathrm{IC}_{50}=3 \mathrm{~nm}\right)^{27,28)}$ (Fig. 1). Two other reports reveal antituberculosis properties of 1,3,4-thiadiazole scaffolds [B and $\mathrm{C}$ ] with aryl substitution at $\mathrm{C} 5$ position. ${ }^{29,30)}$ On the other hand, antimycobacterial potency of thioureas such as isoxyl [E] is well documented. A thiophenyl-thiourea derivative $[\mathrm{F}]$ has been found as a potent inhibitor of mycobacterial growth $\left(\mathrm{IC}_{90}=0.23 \mu \mathrm{g} / \mathrm{mL}\right)^{29}{ }^{29}$ In a previous report, we identified a thiourea derivative linked with 3-alkylthio-1,2,4-triazole moiety [D] as an inhibitor of M. tuberculosis $\mathrm{H}_{37} \mathrm{Rv}$ though it has a low selectivity. ${ }^{\text {) }}$

Considering the findings above and in continuation of our efforts for the development of anti-infective agents, we undertook the design and synthesis of some novel prototypes which possess advantage of the two pharmacophores of thiourea and 1,3,4-thiadiazole in single molecular backbone. Our design strategy included to combine the antimycobacterial pharmacophores (indicated in dashed boxes), a 2-amino/5-aryl substituted 1,3,4-thiadiazole ring $[\mathrm{A}, \mathrm{B}, \mathrm{C}]$ with aryl/heteroaryl thiourea moiety [D, E, F], as illustrated in Fig. 2. During the course of this study, we synthesized and characterized hybrid compounds comprising thiourea and 1,3,4-thiadiazole motifs and evaluated them for their anti-tuberculosis activity against M. tuberculosis H37Rv strain, whereas their cytotoxicity profile was assayed by using Vero cells.

\section{MATERIALS AND METHODS}

Synthetic Chemistry All solvents and reagents were obtained from commercial sources and used without purification. All melting points $\left({ }^{\circ} \mathrm{C}\right.$, uncorrected) were determined using Kleinfeld SMP-II basic model melting point apparatus. Elemental analyses were obtained using Elementar Analysensysteme GmbH varioMICRO CHNS and are consistent with the assigned structures. Infrared spectra were recorded on a Shimadzu FTIR 8400S and data are expressed in wavenumber $v\left(\mathrm{~cm}^{-1}\right)$. NMR spectra were recorded on Bruker AVANCEDPX 400 at $400 \mathrm{MHz}$ for ${ }^{1} \mathrm{H}-\mathrm{NMR}$ and $100 \mathrm{MHz}$ for ${ }^{13} \mathrm{C}-\mathrm{NMR}$ (decoupled), the chemical shifts were expressed in $\delta$ (ppm) downfield from tetramethylsilane (TMS) using dimethyl sulfoxide (DMSO)- $d_{6}$ as solvent. High resolution (HR) electron impact (EI) and FAB-MS was recorded on a Jeol JMS-700 instrument. HR electrospray ionization (ESI)-MS was recorded on a ICR Apex-Qe instruments. The liquid chromatographic system consists of an Agilent technologies 1100 series instrument equipped with a quaternary solvent delivery system and a model Agilent series G1315 A photodiode array detector. A Rheodyne syringe loading sample injector with a $50 \mu \mathrm{L}$ sample loop was used for the injection of the analytes. Chro- 




Fig. 2. Structures of Previously Reported 1,3,4-Thiadiazoles and Disubstituted Thioureas as Inhibitors of M. tuberculosis and the Strategy Employed for Designing Thiadiazolyl Thioureas

matographic data were collected and processed using Agilent Chemstataion Plus software. The separation was performed at ambient temperature by using a reversed phase Kromasil 5C-18 $(4.6 \times 250 \mathrm{~mm}, 5 \mu \mathrm{m}$ particle size $)$ column. All experiments were performed in gradient mode. The mobile phase was prepared by mixing acetonitrile and bidistilled water (50:50 v/v during $0-3 \mathrm{~min}, 75: 25 \mathrm{v} / \mathrm{v}$ during 3-5 min, 100:0 $\mathrm{v} / \mathrm{v}$ during $5-7 \mathrm{~min}, 100: 0 \mathrm{v} / \mathrm{v}$ during $7-12 \mathrm{~min}, 75: 25 \mathrm{v} / \mathrm{v}$ during $12-15 \mathrm{~min}, 50: 50 \mathrm{v} / \mathrm{v}$ during $15-18 \mathrm{~min}$ ) and filtered through a $0.45 \mu \mathrm{m}$ pore filter and subsequently degassed by ultrasonication, prior to use. Solvent delivery was employed at a flow rate of $1 \mathrm{~mL} \cdot \mathrm{min}^{-1}$. Detection of the analytes was carried out at 254 and $280 \mathrm{~nm}$.

Synthesis of 1-Aroylthiosemicarbazides 1, 2 were carried out according to the procedure given in lit $^{24)}$; 4 -chlorobenzoylthiosemicarbazide 1 (melting point (mp): $214^{\circ} \mathrm{C} \mathrm{lit}^{31)}$ : $218-220^{\circ} \mathrm{C}$ ), 4 -fluorobenzoylthiosemicarbazide $\mathbf{2}$ (mp: $180^{\circ} \mathrm{C}$ lit $^{31)}: 172^{\circ} \mathrm{C}$ ).

Synthesis of 2-Amino-5-(4-substituted phenyl)-1,3,4thiadiazoles 3,4 were performed according to the literature method $^{24)}$; 2-amino-5-(4-chlorophenyl)-1,3,4-thiadiazole 3 (mp: $230^{\circ} \mathrm{C} \mathrm{lit}^{32}$ : $226-227^{\circ} \mathrm{C}$ ), 2-amino-5-(4-fluorophenyl)1,3,4-thiadiazole 4 (mp: $240^{\circ} \mathrm{C} \mathrm{lit}^{33)}: 232-234^{\circ} \mathrm{C}$ ).

Synthesis of 1-[5-(4-Chloro/4-fluorophenyl)-1,3,4-thiadiazole-2-yl]-3-substituted Thioureas 5-20 The solution of 5-(4-chloro/4-fluorophenyl)-1,3,4-thiadiazol-2-amine $(3,4)$ in acetonitrile was reacted with equimolar amounts of appropriate isothiocyanates at $140^{\circ} \mathrm{C}$ for $20 \mathrm{~h}$. Acetonitrile was evaporated under vacuo and the solid precipitated was washed with $\mathrm{HCl} 5 \%$ at $70^{\circ} \mathrm{C}$ and then recrystallized from appropriated solvents.

1-[5-(4-Chlorophenyl)-1,3,4-thiadiazole-2-yl]-3-[2(morpholine-4-yl)ethyl]thiourea (5)

${ }^{1} \mathrm{H}-\mathrm{NMR} \quad\left(400 \mathrm{MHz}, \mathrm{DMSO}-d_{6}\right) \quad \delta: 2.43-2.55 \quad(4 \mathrm{H}, \mathrm{m})$, 3.47-3.85 (8H, m), $7.57(2 \mathrm{H}, \mathrm{d}, J=8.5 \mathrm{~Hz}), 7.92(2 \mathrm{H}, \mathrm{d}$, $J=8.5 \mathrm{~Hz}), 8.47$ and $8.61(1 \mathrm{H}$, brs and brs), $12.37(1 \mathrm{H}$, brs). ${ }^{13} \mathrm{C}-\mathrm{NMR}\left(100 \mathrm{MHz}, \mathrm{DMSO}-d_{6}\right) \delta: 53.35$ and 53.72 (d), 56.47 (s), 65.45 (s), 66.85 (s), 128.79 (s), 129.86 (s), 130.07 (s), 135.64 (s), 157.66 (s), 163.96 (s), 180.49 (s). IR, $\mathrm{cm}^{-1}$ : 3321, 1654, 1114. HR-MS (EI ${ }^{+}$) m/z: 383.0649 (Calcd for $\mathrm{C}_{15} \mathrm{H}_{18}{ }^{35} \mathrm{ClN}_{5} \mathrm{O}^{32} \mathrm{~S}_{2}$ : 383.0641), 349.0879 (Calcd for $\mathrm{C}_{15} \mathrm{H}_{17} \mathrm{~N}_{5} \mathrm{O}^{32} \mathrm{~S}^{34} \mathrm{~S}$ : 349.0874). HPLC $t_{\mathrm{R}}$ (min): $10.45 . \mathrm{mp}: 247-249^{\circ} \mathrm{C}$ (acetonitrile).

1-[5-(4-Chlorophenyl)-1,3,4-thiadiazole-2-yl]-3-[2-(phenyl)ethyl]thiourea (6)

${ }^{1} \mathrm{H}-\mathrm{NMR}\left(400 \mathrm{MHz}, \mathrm{DMSO}-d_{6}\right) \delta: 2.91(2 \mathrm{H}, \mathrm{t}, J=7.2 \mathrm{~Hz})$, 3.73-3.78 (2H, m), 7.21-7.35 (5H, m), $7.57(2 \mathrm{H}, \mathrm{d}, J=8.5 \mathrm{~Hz})$, $7.91(2 \mathrm{H}, \mathrm{d}, J=8.5 \mathrm{~Hz}), 8.61(1 \mathrm{H}$, brs $), 12.41(1 \mathrm{H}, \mathrm{brs})$. ${ }^{13} \mathrm{C}-\mathrm{NMR}\left(100 \mathrm{MHz}, \mathrm{DMSO}-d_{6}\right) \delta: 34.63$ (s), 46.43 (s), 126.97 (s), 128.58 (s), 128.98 and 129.04 (d), 129.14 and 129.37 (d), 129.47 and 129.66 (d), 130.05 (s), 130.97 (s), 135.01 and 135.55 (d), 139.65 and 139.98 (d), 180.49 (s). IR, $\mathrm{cm}^{-1}$ : 3321, 1641, 1112. HR-MS $\left(\mathrm{EI}^{+}\right.$) $\mathrm{m} / \mathrm{z}$ : 374.0473 (Calcd for $\mathrm{C}_{17} \mathrm{H}_{15}{ }^{35} \mathrm{ClN}_{4}{ }^{32} \mathrm{~S}_{2}$ : 374.0426), 340.0526 (Calcd for $\mathrm{C}_{17} \mathrm{H}_{13}{ }^{35} \mathrm{ClN}_{4}{ }^{32} \mathrm{~S}: 340.0549$ ). HPLC $t_{\mathrm{R}}$ (min): $10.59 . \mathrm{mp}: 244^{\circ} \mathrm{C}$ (acetonitrile).

1-[5-(4-Chlorophenyl)-1,3,4-thiadiazole-2-yl]-3-[2-(4chlorophenyl)ethyl]thiourea (7)

${ }^{1} \mathrm{H}-\mathrm{NMR} \quad\left(400 \mathrm{MHz}, \mathrm{DMSO}-d_{6}\right) \quad \delta: 2.84-2.96 \quad(2 \mathrm{H}, \mathrm{m})$, 3.75-3.82 (2H, m), 7.21-7.35 (4H, m), 7.57-7.62 (2H, m), 
$7.78-7.93$ (2H, m), 8.70 (1H, brs), 11.99 (1H, brs). ${ }^{13} \mathrm{C}-\mathrm{NMR}$ $\left(100 \mathrm{MHz}, \mathrm{DMSO}-d_{6}\right) \delta: 33.82$ (s), 46.09 (s), 128.81 and 128.86 (d), 129.81 (s), 131.09 (s), 131.71 (s), 135.67 (s), 138.55 (s), 180.49 (s). IR, cm ${ }^{-1}: 3321,1641,1112,1089$. HR-MS $\left(\mathrm{EI}^{+}\right)$ $m / z$ : 408.0039 (Calcd for $\mathrm{C}_{17} \mathrm{H}_{14}{ }^{37} \mathrm{Cl}_{2} \mathrm{~N}_{4} \mathrm{~S}_{2}$ : 408.0037), 374.0152 (Calcd for $\mathrm{C}_{17} \mathrm{H}_{12}{ }^{37} \mathrm{ClN}_{4} \mathrm{~S}$ : 374.0159). HPLC $t_{\mathrm{R}}$ (min): 10.58 . $\mathrm{mp}: 222-223^{\circ} \mathrm{C}$ (acetonitrile).

1-[5-(4-Chlorophenyl)-1,3,4-thiadiazole-2-yl]-3-(benzoyl)thiourea $(8)$

${ }^{1} \mathrm{H}-\mathrm{NMR} \quad\left(400 \mathrm{MHz}, \quad \mathrm{DMSO}-d_{6}\right) \quad \delta: 7.56-7.64 \quad(4 \mathrm{H}, \mathrm{m})$, 7.67-7.72 (1H, m), 8.01-8.04 $(3 \mathrm{H}, \mathrm{m}), 8.14(1 \mathrm{H}, \mathrm{d}, J=7.2 \mathrm{~Hz})$, $12.29(1 \mathrm{H}$, brs $), 13.23$ and $14.38\left(1 \mathrm{H}\right.$, brs and brs). ${ }^{13} \mathrm{C}-\mathrm{NMR}$ $\left(100 \mathrm{MHz}, \mathrm{DMSO}-d_{6}\right) \delta$ : 116.99 and 117.28 (d), 127.47 (s), 129.11 and 129.89 (d), 130.01 (s), 132.06 (s), 133.76 (s), 134.21 (s), 160.03 (s), 161.69 (s), 162.38 (s), 181.33 (s). IR, $\mathrm{cm}^{-1}$ : 3321, 1670, 1641, 1176. HR-MS $\left(\mathrm{EI}^{+}\right) \mathrm{m} / \mathrm{z}: 376.0016$ (Calcd for $\mathrm{C}_{16} \mathrm{H}_{11}{ }^{37} \mathrm{ClN}_{4} \mathrm{OS}_{2}$ : 376.0063 ), 374.0057 (Calcd for $\mathrm{C}_{16} \mathrm{H}_{11}{ }^{35} \mathrm{ClN}_{4} \mathrm{OS}_{2}$ : 374.0063), 105.0315 (Calcd for $\mathrm{C}_{7} \mathrm{H}_{5} \mathrm{O}$ : 105.0334), 77.0422 (Calcd for $\mathrm{C}_{6} \mathrm{H}_{5}$ : 77.0385). HPLC $t_{\mathrm{R}}$ (min): 10.64. mp: $313-315^{\circ} \mathrm{C}$ (acetonitrile).

1-[5-(4-Chlorophenyl)-1,3,4-thiadiazole-2-yl]-3-(4cyanophenyl)thiourea (10)

${ }^{1} \mathrm{H}-\mathrm{NMR}\left(400 \mathrm{MHz}, \mathrm{DMSO}-d_{6}\right) \delta: 7.58(2 \mathrm{H}, \mathrm{d}, J=6.6 \mathrm{~Hz})$, $7.37(2 \mathrm{H}, \mathrm{d}, J=8.7 \mathrm{~Hz}), 7.89(2 \mathrm{H}, \mathrm{d}, J=10.8 \mathrm{~Hz}), 7.99(2 \mathrm{H}$, d, $J=8.7 \mathrm{~Hz}), 8.70$ (1H, brs), 10.90 (1H, brs). ${ }^{13} \mathrm{C}-\mathrm{NMR}$ $\left(100 \mathrm{MHz}, \mathrm{DMSO}-d_{6}\right) \quad \delta$ : 105.42 (s), 119.93 (s), 121.94 (s), 128.96 (s), 129.44 (s), 130.16 (s), 133.52 (s), 136.29 (s), 144.51 (s), 154.15 (s), 169.52 (s), 185.52 (s). IR, $\mathrm{cm}^{-1}$ : 3311, 2205, 1641, 1176. HR-MS $\left(\mathrm{EI}^{+}\right.$) $\mathrm{m} / \mathrm{z}$ : 371.0027 (Calcd for $\mathrm{C}_{16} \mathrm{H}_{10}{ }^{35} \mathrm{ClN}_{5} \mathrm{~S}_{2}$ : 371.0066), 337.0181 (Calcd for $\mathrm{C}_{16} \mathrm{H}_{8}{ }^{35} \mathrm{ClN}_{5} \mathrm{~S}$ : 337,0188), 252.9544 (Calcd for $\mathrm{C}_{9} \mathrm{H}_{4}{ }^{35} \mathrm{ClN}_{3} \mathrm{~S}_{2}$ : 252.9535), 118.0539 (Calcd for $\mathrm{C}_{7} \mathrm{H}_{6} \mathrm{~N}_{2}$ : 118.0531). HPLC $t_{\mathrm{R}}(\mathrm{min})$ : 9.68. $\mathrm{mp}: 263-264^{\circ} \mathrm{C}$ (methanol).

1-[5-(4-Chlorophenyl)-1,3,4-thiadiazole-2-yl]-3-(4fluorophenyl)thiourea (11)

${ }^{1} \mathrm{H}-\mathrm{NMR}\left(400 \mathrm{MHz}, \mathrm{DMSO}-d_{6}\right) \delta: 7.16(2 \mathrm{H}, \mathrm{t}, J=8.4 \mathrm{~Hz})$, 7.49-7.76 (4H, m), 7.88-7.97 (3H, m, ) 10.56 (1H, brs). ${ }^{13} \mathrm{C}-\mathrm{NMR}\left(100 \mathrm{MHz}, \mathrm{DMSO}-d_{6}\right) \delta$ : 115.57 and 115.87 (d), 128.59 (s), 128.89 (s), 129.64 (s), 130.13 (s), 136.06 (s), 136.62 (s), 180.49 (s). IR, $\mathrm{cm}^{-1}$ : 3327, 1653, 1637, 1229, 1176. HR-MS (EI $\left.{ }^{+}\right) m / z: 364.0007$ (Calcd for $\mathrm{C}_{15} \mathrm{H}_{10}{ }^{35} \mathrm{ClFN}_{4} \mathrm{~S}_{2}$ : 364.0019), 330.0129 (Calcd for $\mathrm{C}_{15} \mathrm{H}_{8}{ }^{35} \mathrm{ClFN}_{4} \mathrm{~S}$ : 330.0142), 252.9545 (Calcd for $\mathrm{C}_{9} \mathrm{H}_{4}{ }^{35} \mathrm{ClN}_{3} \mathrm{~S}_{2}$ : 252.9535), 111.0471 (Calcd for $\mathrm{C}_{6} \mathrm{H}_{6} \mathrm{NF}$ : 111.0484). HPLC $t_{\mathrm{R}}$ (min): 9.95. mp: $283-284^{\circ} \mathrm{C}$ (methanol).

1-[5-(4-Chlorophenyl)-1,3,4-thiadiazole-2-yl]-3-(3,5bistrifluoromethylphenyl)thiourea (12)

${ }^{1} \mathrm{H}-\mathrm{NMR} \quad\left(400 \mathrm{MHz}, \mathrm{DMSO}-d_{6}\right) \quad \delta: 7.47-7.52 \quad(2 \mathrm{H}, \mathrm{m})$, 7.57-7.61 (1H, m), 7.72-7.76 (2H, m), 7.84 (1H, s), 7.89-7.95 $(1 \mathrm{H}, \mathrm{m}), 8.17$ and $8.44(1 \mathrm{H}, \mathrm{s}$ and $\mathrm{s}), 10.99$ and $11.65(1 \mathrm{H}, \mathrm{s}$ and s). ${ }^{13} \mathrm{C}-\mathrm{NMR}\left(100 \mathrm{MHz}, \mathrm{DMSO}-d_{6}\right) \delta$ : 118.31 (s), 121.94 (s), 122.36 (s), 125.75 (s), 128.58 (s), 129.86 (s), 130.86 (s), 131.50 (s), 134.67 (s), 136.32 (s), 141.76 (s), 155.84 (s), 169.53 (s), 189.45 (s). IR, $\mathrm{cm}^{-1}: 3213,1630,1176 . \mathrm{HR}-\mathrm{MS}\left(\mathrm{EI}^{+}\right) \mathrm{m} / \mathrm{z}$ : 481.9849 (Calcd for $\mathrm{C}_{17} \mathrm{H}_{9}{ }^{35} \mathrm{ClF}_{6} \mathrm{~N}_{4} \mathrm{~S}_{2}$ : 481.9861), 447.9963 (Calcd for $\left.\mathrm{C}_{17} \mathrm{H}_{7}{ }^{35} \mathrm{ClF}_{6} \mathrm{~N}_{4} \mathrm{~S}: 447.9984\right)$. HPLC $t_{\mathrm{R}}$ (min): 11.54 . mp: $296-299^{\circ} \mathrm{C}$ (methanol).

1-[5-(4-Chlorophenyl)-1,3,4-thiadiazole-2-yl]-3-(5-chloro-2methylphenyl)thiourea (13)

${ }^{1} \mathrm{H}-\mathrm{NMR}\left(400 \mathrm{MHz}, \mathrm{DMSO}-d_{6}\right) \delta: 2.15(3 \mathrm{H}, \mathrm{s}), 7.21-7.36$ $(3 \mathrm{H}, \mathrm{m}), 7.55-7.76(3 \mathrm{H}, \mathrm{m}), 7.86(2 \mathrm{H}, \mathrm{d}, J=8.4 \mathrm{~Hz}), 10.14(1 \mathrm{H}$, brs). ${ }^{13} \mathrm{C}-\mathrm{NMR}\left(100 \mathrm{MHz}, \mathrm{DMSO}-d_{6}\right) \delta$ : 18.00 (s), 128.92 (s),
129.64 (s), 130.11 (s), 130.46 (s), 134.01 (s), 132.52 (s), 135.99 (s), 139.74 (s), 189.45 (s). IR, $\mathrm{cm}^{-1}$ : 3313, 1641, 1176. HR-MS (EI ${ }^{+}$) $m / z$ : 393.9869 (Calcd for $\mathrm{C}_{16} \mathrm{H}_{12}{ }^{35} \mathrm{Cl}_{2} \mathrm{~N}_{4} \mathrm{~S}_{2}$ : 393.9880), 360.0010 (Calcd for $\left.\mathrm{C}_{16} \mathrm{H}_{10}{ }^{35} \mathrm{Cl}_{2} \mathrm{~N}_{4} \mathrm{~S}: 360.0003\right)$. HPLC $t_{\mathrm{R}}$ (min): 10.64. mp: $284-286^{\circ} \mathrm{C}$ (methanol).

1-[5-(4-Chlorophenyl)-1,3,4-thiadiazole-2-yl]-3-(2-chloro-5trifluoromethylphenyl)thiourea (14)

${ }^{1} \mathrm{H}-\mathrm{NMR} \quad\left(400 \mathrm{MHz}, \quad \mathrm{DMSO}-d_{6}\right) \quad \delta: 7.56-7.65 \quad(4 \mathrm{H}, \mathrm{m})$, $7.76(1 \mathrm{H}, \mathrm{d}, J=8.7 \mathrm{~Hz}), 7.87-7.98(3 \mathrm{H}, \mathrm{m}), 10.33(1 \mathrm{H}, \mathrm{brs})$. ${ }^{13} \mathrm{C}-\mathrm{NMR} \quad\left(100 \mathrm{MHz}, \mathrm{DMSO}-d_{6}\right) \quad \delta: 122.42 \quad(\mathrm{~s}), 124.11 \quad(\mathrm{~s})$, 125.10 (s), 126.03 (s), 126.84 (s), 128.44 (s), 129.53 (s), 130.15 (s), 135.34 (s), 136.12 (s), 138.02 (s), 180.49 (s). IR, $\mathrm{cm}^{-1}:$ 3286, 3204, 1634, 1121. HR-MS (FAB) $\mathrm{m} / \mathrm{z}: 448.9626$ (Calcd for $\mathrm{C}_{16} \mathrm{H}_{10}{ }^{35} \mathrm{Cl}_{2} \mathrm{~F}_{3} \mathrm{~N}_{4} \mathrm{~S}_{2}$ : 448.9670), 414.9787 (Calcd for $\mathrm{C}_{16} \mathrm{H}_{8}{ }^{35} \mathrm{Cl}_{2} \mathrm{~F}_{3} \mathrm{~N}_{4} \mathrm{~S}$ : 414.9793). HPLC $t_{\mathrm{R}}$ (min): 11.30. mp: $306-309^{\circ} \mathrm{C}$ (methanol).

1-[5-(4-Chlorophenyl)-1,3,4-thiadiazole-2-yl]-3-(4-chloro-3trifluoromethylphenyl)thiourea (15)

${ }^{1} \mathrm{H}-\mathrm{NMR}\left(400 \mathrm{MHz}, \mathrm{DMSO}-d_{6}\right) \delta: 7.53-7.70(3 \mathrm{H}, \mathrm{m}), 7.85$ (2H, d, $J=8.7 \mathrm{~Hz}), 8.08-8.16$ (2H, m), 9.61 (1H, brs), 10.84 $\left(1 \mathrm{H}\right.$, brs). ${ }^{13} \mathrm{C}-\mathrm{NMR}\left(100 \mathrm{MHz}, \mathrm{DMSO}-d_{6}\right) \delta$ : 117.98 (s), 121.26 and 121.59 (d), 124.3 and 124.92 (d), 125.22 (s), 128.55 and 128.84 (d), 129.20 and 129.44 (d), 129.66 and 129.82 (d), 130.03 (s), 131.01 (s), 132.23 and 132.69 (d), 136.21 (s), 139.77 (s), 154.09 (s), 185.32 (s). IR, $\mathrm{cm}^{-1}$ : 3327, 1653, 1136, 1121. HR-MS (FAB) $m / z$ : 448.9673 (Calcd for $\mathrm{C}_{16} \mathrm{H}_{10}{ }^{35} \mathrm{Cl}_{2} \mathrm{~F}_{3} \mathrm{~N}_{4} \mathrm{~S}_{2}$ : 448.9670), 414.9826 (Calcd for $\mathrm{C}_{16} \mathrm{H}_{8}{ }^{35} \mathrm{Cl}_{2} \mathrm{~F}_{3} \mathrm{~N}_{4} \mathrm{~S}$ : 414.9793). HPLC $t_{\mathrm{R}}$ (min): 11.40. mp: $298-302^{\circ} \mathrm{C}$ (methanol).

1 - [5-(4-Fluorophenyl)-1,3,4-thiadiazole-2-yl]-3benzoylthiourea (16)

${ }^{1} \mathrm{H}-\mathrm{NMR} \quad\left(400 \mathrm{MHz}, \quad \mathrm{DMSO}-d_{6}\right) \quad \delta: 7.36-7.64 \quad(5 \mathrm{H}, \mathrm{m})$, 8.01-8.11 (4H, m), 12.31 (1H, brs), 13.15 (1H, brs). ${ }^{13} \mathrm{C}-\mathrm{NMR}$ $\left(100 \mathrm{MHz}, \mathrm{DMSO}-d_{6}\right) \delta$ : 116.99 and 117.28 (d), 127.47 (s), 129.11 and 129.89 (d), 130.01 (s), 132.06 (s), 133.76 (s), 134.21 (s), 160.03 (s), 161.69 and 162.38 (d), 165.68 (s), 181.33 (s). IR, $\mathrm{cm}^{-1}: 3306,1672,1635,1220,1153$. HR-MS (ESI) $\mathrm{m} / \mathrm{z}$ : 359.0433 (Calcd for $\mathrm{C}_{16} \mathrm{H}_{12} \mathrm{FN}_{4} \mathrm{OS}_{2}: 359.0431$ ). HPLC $t_{\mathrm{R}}$ (min): 8.75. mp: $262^{\circ} \mathrm{C}$ (methanol).

1 -[5-(4-Fluorophenyl)-1,3,4-thiadiazole-2-yl]-3-(4cyanophenyl)thiourea (18)

${ }^{1} \mathrm{H}-\mathrm{NMR}\left(400 \mathrm{MHz}, \mathrm{DMSO}-d_{6}\right) \delta: 7.37(2 \mathrm{H}, \mathrm{t}, J=8.1 \mathrm{~Hz})$, $7.73(2 \mathrm{H}, \mathrm{d}, J=8.7 \mathrm{~Hz}), 7.93-8.02(5 \mathrm{H}, \mathrm{m}), 10.88(1 \mathrm{H}, \mathrm{s})$. ${ }^{13} \mathrm{C}-\mathrm{NMR}\left(100 \mathrm{MHz}, \mathrm{DMSO}-d_{6}\right) \quad \delta: 105.37$ (s), 117.08 and 117.38 (d), 121.92 (s), 127.16 and 127.20 (d), 129.63 and 129.75 (d), 133.52 (s), 144.54 (s), 162.58 (s), 165.89 (s), 180.49 (s). IR, $\mathrm{cm}^{-1}$ : 3313, 2207, 1658, 1234, 1157. HR-MS (ESI) $\mathrm{m} / \mathrm{z}$ : 356.0437 (Calcd for $\left.\mathrm{C}_{16} \mathrm{H}_{11} \mathrm{FN}_{5} \mathrm{~S}_{2}: 356.0434\right)$ ). HPLC $t_{\mathrm{R}}$ (min): 8.53. mp: $281-283^{\circ} \mathrm{C}$ (methanol).

1-[5-(4-Fluorophenyl)-1,3,4-thiadiazole-2-yl]-3-(4fluorophenyl)thiourea (19)

${ }^{1} \mathrm{H}-\mathrm{NMR}\left(400 \mathrm{MHz}, \mathrm{DMSO}-d_{6}\right) \delta: 7.16(2 \mathrm{H}, \mathrm{t}, J=7.8 \mathrm{~Hz})$, $7.36(3 \mathrm{H}, \mathrm{t}, J=8.7 \mathrm{~Hz}), 7.64-7.68(2 \mathrm{H}, \mathrm{m}), 7.91-8.01(2 \mathrm{H}, \mathrm{m})$, $10.55(1 \mathrm{H}, \mathrm{s}) .{ }^{13} \mathrm{C}-\mathrm{NMR}\left(100 \mathrm{MHz}, \mathrm{DMSO}-d_{6}\right) \delta: 115.57$ and 115.86 (d), 117.03 and 117.33 (d), 127.36 (s), 129.53 and 129.65 (d), 136.63 (s), 162.46 (s), 165.76 (s), 180.49 (s). IR, cm ${ }^{-1}: 3325$, 3201, 1651, 1224, 1155. HR-MS (ESI) m/z: 349.0392 (Calcd for $\left.\mathrm{C}_{15} \mathrm{H}_{11} \mathrm{~F}_{2} \mathrm{~N}_{4} \mathrm{~S}_{2}: 349.0387\right)$. HPLC $t_{\mathrm{R}}$ (min): 9.02. mp: $293-295^{\circ} \mathrm{C}$ (methanol).

1-[5-(4-Fluorophenyl)-1,3,4-thiadiazole-2-yl]-3-(4-chloro-3trifluoromethylphenyl)thiourea (20)

${ }^{1} \mathrm{H}-\mathrm{NMR} \quad\left(400 \mathrm{MHz}, \quad \mathrm{DMSO}-d_{6}\right) \quad \delta: 7.37-7.63 \quad(4 \mathrm{H}, \mathrm{m})$, 
$7.92-7.97$ (3H, m), $8.13(1 \mathrm{H}, \mathrm{s}), 10.84$ (1H, s). ${ }^{13} \mathrm{C}-\mathrm{NMR}$ $\left(100 \mathrm{MHz}, \mathrm{DMSO}-d_{6}\right) \delta: 31.39$ (s), 117.08 and 117.37 (d), 127.24 (s), 129.61 and 129.73 (d), 132.29 (s), 139.80 (s), 162.56 (s), 207.24 (s). IR, $\mathrm{cm}^{-1}: 3329,3225,1651,1226,1159$. HR-MS (ESI) $m / z$ : 432.9972 (Calcd for $\mathrm{C}_{16} \mathrm{H}_{11} \mathrm{ClF}_{4} \mathrm{~N}_{4} \mathrm{~S}_{2}$ : 432.9966). HPLC $t_{\mathrm{R}}(\mathrm{min}): 10.21$. mp: $299-301^{\circ} \mathrm{C}$ (methanol).

Anti-tuberculosis Activity The antituberculosis activity of compounds was tested against M. tuberculosis $H 37 R v$ strain. For the MIC determination, the compounds were dissolved in DMSO and serial two fold dilutions were done in Middlebrook 7H9 broth with glycerol. Microorganisms were suspended in Middlebrook $7 \mathrm{H} 9$ broth to match the turbidity of $0.5 \mathrm{McFarland}\left(1.5 \times 10^{8} \mathrm{cfu} / \mathrm{mL}\right)$ and $1 / 10$ dilution was prepared from this suspension and used as inoculum. The tested final concentrations ranged between 512 to $0.5 \mu \mathrm{g} / \mathrm{mL}$. To make sure that DMSO did not show any inhibitory activity, controls prepared with serial dilutions of DMSO were also tested. Tubes were incubated at $37^{\circ} \mathrm{C}$ for $24 \mathrm{~h}$ and then examined for turbidity. MIC was determined if turbidity was observed in the positive control tube containing no compound and no turbidity in the negative control tube containing no microorganism. ${ }^{34-36)}$

Antimicrobial Activity The antimicrobial activities of all compounds were evaluated in the Department of Genetics and Bioengineering, Faculty of Engineering and Architecture, Yeditepe University. The antibacterial and antifungal activities of the compounds were evaluated against 8 microbial cultures isolates of 6 bacteria and 1 yeast species by micro-well dilution assay as described below. ${ }^{37)}$ Microorganisms were provided by the Department of Genetics and Bioengineering, Faculty of Engineering and Architecture, Yeditepe University, Istanbul, Turkey. The microorganisms used were Staphylococcus aureus, Escherichia coli, Bacillus subtilis, Klebsiella pneumoniae, Pseudomonas aeruginosa, Staphylococcus epidermidis and Candida albicans. Ampicillin, Cefepime and Amphotericin B were used as the positive sensitivity reference standard for bacteria and yeast.

Micro-well Dilution Assay The sensitivity of the bacterial strains towards the compounds was quantitatively evaluated from the MIC values obtained by the micro-well dilution method. The inocula of the bacterial strains were prepared from 12-h broth cultures and suspensions were adjusted to 0.5 McFarland standard turbidity. Compounds dissolved in DMSO were first prepared at the highest concentration to be tested
$(200 \mu \mathrm{g} / \mathrm{mL})$, and then serial two-fold dilutions were made in order to obtain a concentration range from 6.25 to $200 \mu \mathrm{g} / \mathrm{mL}$, in $15-\mathrm{mL}$ sterile test tubes containing nutrient broth. The $96-$ well plates were prepared by dispensing into each well $95 \mu \mathrm{L}$ of nutrient broth and $5 \mu \mathrm{L}$ of the inoculum. Two hundred microliters of nutrient broth without inoculum was transferred into the first wells as positive control. Aliquots, $(100 \mu \mathrm{L})$ taken from the $200-\mu \mathrm{g} / \mathrm{mL}$ stock solution, were added to the second well.

One hundred microliters from the respective serial dilutions was transferred into 5 consecutive wells. The last well containing $195 \mu \mathrm{L}$ of nutrient broth without compound and $5 \mu \mathrm{L}$ of the inoculum on each strip was used as negative control. Contents of each well were mixed on plate shaker at $300 \mathrm{rpm}$ for $20 \mathrm{~s}$ and then incubated at appropriate temperatures for $24 \mathrm{~h}$. Microbial growth in each medium was determined by reading the absorbance (Abs) at $630 \mathrm{~nm}$ using the ELx 800 universal microplate reader (Biotek Instrument Inc., Highland Park, VT, U.S.A.) and confirmed by plating $5-\mu \mathrm{L}$ samples from clear wells on nutrient agar medium. The MIC was defined as the lowest concentration of the compounds to inhibit the growth of microorganisms. Cefepime (Maxipime ${ }^{\circledR}$, BristolMyers Squibb, Istanbul, Turkey) at the concentration range of $500-7.8 \mu \mathrm{g} / \mathrm{mL}$ was prepared in nutrient broth and used as standard drug for positive control.

In Vitro Antiviral Assays A detailed account of experimental data related to in vitro antiviral assays (inhibition of human immunodeficiency virus (HIV)-induced cytopathicity in MT-4 cells, antiviral assays other than HIV and anti-influenza assays) were given in literature. ${ }^{38)}$

\section{RESULTS AND DISCUSSION}

Chemistry 4-Chlorobenzoylthiosemicarbazide 1, 4-fluorobenzoylthiosemicarbazide 2 , their corresponding 1,3,4-thiadiazoles; 2-amino-5-(4-chlorophenyl)-1,3,4-thiadiazole 3 and 2-amino-5-(4-fluorophenyl)-1,3,4-thiadiazole 4, were synthesized according to the procedures given in literature. ${ }^{24)}$ Their purity were checked by TLC and HPLC and melting points of compounds 1-4 are found to be in accordance with literature. ${ }^{31-33)}$ Synthetic route to compounds 5-20 is presented in Chart 1. As the final step, 5-(4-substituted phenyl)-1,3,4thiadiazol-2-amines $(\mathbf{3}, \mathbf{4})$ were reacted with appropriate isothiocyanates in acetonitrile to yield 1-[5-(4-substituted

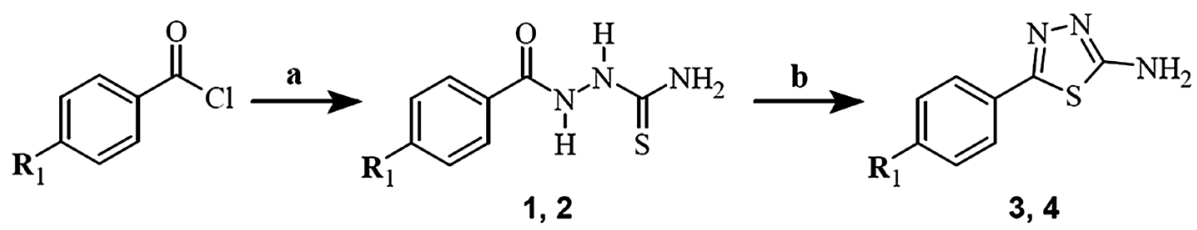<smiles>[R2]NC(=S)Nc1nnc(-c2ccc([R])cc2)s1</smiles>

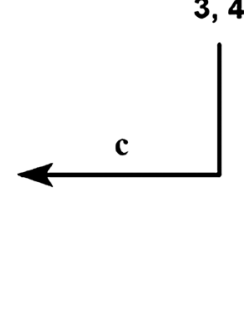

Reagents and conditions: (a) acetone $/ \mathrm{NaHCO}_{3}$; (b) $\mathrm{H}_{2} \mathrm{SO}_{4}$ (conc.), rt; (c) $\mathrm{R}_{2}$-NCS/ACN, reflux.

Chart 1. Synthetic Route to Compounds 1-20 
phenyl)-1,3,4-thiadiazole-2-yl]-3-substituted thioureas 5-20. The purity of the synthesized compounds were checked by TLC and HPLC. Since synthesis procedure and structural characterization data of compounds $\mathbf{9}$ and $\mathbf{1 7}$ were already reported by George et al., ${ }^{39)}$ spectral data were not provided for these compounds.

HR-MS confirmed the molecular weights and empirical formulae of compounds $\mathbf{5 - 2 0}$, with less than $5 \mathrm{mmu}$ bias between calculated and experimental $\mathrm{m} / \mathrm{z}$ values of molecular ions. Ionization mode was EI for compounds 5-13. Compounds 14 and 15 which were analysed using FAB procedure and they demonstrated $\mathrm{MH}^{+}$peaks instead of molecular ion $\left(\mathrm{M}^{+}\right)$ peaks. Compounds 16-20 were also analysed using another soft ionization technique; ESI procedure and their $\mathrm{MH}^{+}$peaks were determined. The mass of $\mathrm{M}^{+}$peaks and experimental fragments of compounds $\mathbf{5}-\mathbf{1 3}$ and $\mathrm{MH}^{+}$peaks of compounds 14-20 match the mass of corresponding calculated ones. Compounds 5-13 cleave off $\mathrm{H}_{2} \mathrm{~S}$ forming carbodiimide fragments in accordance with literature. ${ }^{40)}$ Compounds $\mathbf{1 0}$ and $\mathbf{1 1}$ allow unambiguous fragmentations of characteristics product ions for thiourea based compounds yielding the common 2-(4-chlorophenyl)-5-isothiocyanato-1,3,4-thiadiazole fragment at $\mathrm{m} / \mathrm{z} 252.9544$ and as well as 4-aminobenzonitrile fragment at $\mathrm{m} / \mathrm{z} 118.0539$ and 4-fluoroaniline fragment at $\mathrm{m} / \mathrm{z} 111.0471$, respectively. 8,41$)$

The diagnostic N-H strecthing vibrations of thiourea compunds 5-20 appeared in $3128-3361 \mathrm{~cm}^{-1}$ region. ${ }^{42)}$ This wide range and varying number of $\mathrm{N}-\mathrm{H}$ bands may be attributable to intramolecular hydrogen bonds. ${ }^{43)}$ Since a S-H vibration at approximately $2600 \mathrm{~cm}^{-1}$ has not been detected, we may indicate that our thiourea compounds remain in thioketo- amine form in solid state. Fourier transform-infrared (FT-IR) spectra revealed $\mathrm{C}=\mathrm{S}$ strecthing vibrations at $1112-1176 \mathrm{~cm}^{-1}$ region. $^{38)}$

The characteristic $\mathrm{N}^{2}-\mathrm{H}$ signals of thiourea compounds noted as a singlet or two singlets corresponding to one proton at the region of $10.14-12.41 \mathrm{ppm}$. An other characteristic signal $\mathrm{N}^{1}-\mathrm{H}$ was determined either at aromatic region or between $8.13-9.61 \mathrm{ppm}$ due to their intra and/or intermolecular hydrogen bond formation tendency by means of equilibria between syn and anti conformations. ${ }^{44,45)}$ In the ${ }^{1} \mathrm{H}-\mathrm{NMR}$ spectra of compounds $\mathbf{8}$ and $\mathbf{1 6}$ with benzoyl moiety on thiourea structure, $\mathrm{N}^{1}-\mathrm{H}$ was determined at 12.29 and $12.31 \mathrm{ppm}$, respectively and $\mathrm{N}^{2}-\mathrm{H}$ was determined at 13.23 and 14.38 and $13.15 \mathrm{ppm}$, respectively. ${ }^{13} \mathrm{C}-\mathrm{NMR}$ data of representative derivatives was found to be descriptive for carbon framework and detection of $\mathrm{C}=\mathrm{S}$ signal between $180-207 \mathrm{ppm}$ was evaluated as an evidence for thiourea formation. Meanwhile the aromatic carbon resonances due to phenyl and 1,3,4-thiadiazole rings were also observed in expected regions. ${ }^{24,25,39)}$

Antituberculosis Activity All synthesized compounds 5-20 were initially screened for their in vitro antituberculosis activity against $M$. tuberculosis $\mathrm{H}_{37} \mathrm{Rv}$ strain. The MIC vs. $M$. tuberculosis $\mathrm{H}_{37} \mathrm{Rv}$ was determined by a broth microdilution method as previously described (Table 1). Minimum cytotoxic concentration (MCC) on Vero cells was also determined to evaluate the selectivity of the synthesized compounds. Antituberculosis activity and cytotoxicity results of compounds 5-20 were compared to isoniazid (INH) and ethambutol which were used as reference drugs (Table 1).

Compounds having either 4-chlorophenyl (compounds 5-15) or 4-fluorophenyl (compounds 16-20) substituents on

Table 1. In Vitro Antimycobacterial Activity of Compounds 5-20 against M. tuberculosis $\mathrm{H}_{37} \mathrm{Rv}$<smiles>[R2]NC(=S)Nc1nnc(-c2ccc([R])cc2)s1</smiles>

\begin{tabular}{|c|c|c|c|c|c|c|c|c|}
\hline \multirow{2}{*}{ Laboratory code } & \multirow{2}{*}{$\begin{array}{l}\text { Compd } \\
\text { ID }\end{array}$} & \multirow{2}{*}{$\mathrm{R}_{1}$} & \multirow{2}{*}{$\mathrm{R}_{2}$} & \multirow{2}{*}{$\begin{array}{l}\text { MIC } \\
(\mu \mathrm{M})\end{array}$} & \multirow{2}{*}{$\begin{array}{c}\mathrm{MCC}^{a)} \\
(\mu \mathrm{M})\end{array}$} & \multirow{2}{*}{$\begin{array}{c}\mathrm{SI} \\
(\mathrm{MCC} / \mathrm{MIC})\end{array}$} & \multicolumn{2}{|c|}{ PASS prediction ${ }^{c)}$} \\
\hline & & & & & & & $P a$ & $P i$ \\
\hline KUC060101 & 5 & $\mathrm{Cl}$ & 2-(Morpholin-1-yl)ethyl & 83.78 & $>100$ & $>1.2$ & 0.364 & 0.043 \\
\hline KUC060102 & 6 & $\mathrm{Cl}$ & 2-Phenylethyl & 170.70 & 100 & 0.6 & 0.469 & 0.016 \\
\hline KUC060103 & 7 & $\mathrm{Cl}$ & 2-(4-Chlorophenyl)ethyl & 78.17 & 100 & 1.3 & 0.468 & 0.016 \\
\hline KUC060104 & 8 & $\mathrm{Cl}$ & Benzoyl & 170.72 & $>100$ & $>0.6$ & 0.658 & 0.005 \\
\hline KUC060105 & 9 & $\mathrm{Cl}$ & Phenyl & 46.13 & $\geq 20$ & $\geq 0.4$ & 0.684 & 0.004 \\
\hline KUC060106 & 10 & $\mathrm{Cl}$ & 4-Cyanophenyl & 43.02 & $\geq 20$ & $\geq 0.5$ & 0.521 & 0.010 \\
\hline KUC060107 & 11 & $\mathrm{Cl}$ & 4-Fluorophenyl & 10.96 & $\geq \mathbf{2 0}$ & $\geq 1.8$ & 0.582 & 0.006 \\
\hline KUC060108 & 12 & $\mathrm{Cl}$ & 3,5-Bis(trifluoromethyl)phenyl & 33.14 & 20 & 0.6 & 0.563 & 0.007 \\
\hline KUC060109 & 13 & $\mathrm{Cl}$ & 5-Chloro-2-methylphenyl & 80.94 & 20 & 0.2 & 0.638 & 0.005 \\
\hline KUC060110 & 14 & $\mathrm{Cl}$ & 2-Chloro-5-(trifluoromethyl)phenyl & 71.22 & 20 & 0.3 & 0.483 & 0.014 \\
\hline KUC060111 & 15 & $\mathrm{Cl}$ & 4-Chloro-3-(trifluoromethyl)phenyl & 17.81 & 100 & 5.6 & 0.538 & 0.009 \\
\hline KUC060113 & 16 & $\mathrm{~F}$ & Benzoyl & 178.56 & 100 & 0.6 & 0.578 & 0.007 \\
\hline KUC060114 & 17 & $\mathrm{~F}$ & Phenyl & 48.42 & 100 & 2.1 & 0.611 & 0.005 \\
\hline KUC060115 & 18 & $\mathrm{~F}$ & 4-Cyanophenyl & 45.02 & 100 & 2.2 & 0.450 & 0.019 \\
\hline KUC060116 & 19 & $\mathrm{~F}$ & 4-Fluorophenyl & 11.48 & 100 & 8.7 & 0.610 & 0.005 \\
\hline KUC060118 & 20 & $\mathrm{~F}$ & 4-Chloro-3-(trifluoromethyl)phenyl & 36.96 & 4 & 0.1 & 0.458 & 0.018 \\
\hline Isoniazid & & & & $0.073-1.45$ & $\mathrm{ND}^{b)}$ & NA & 0.813 & 0.003 \\
\hline Ethambutol & & & & $6.12-24.47$ & $\mathrm{ND}^{b)}$ & NA & 0.926 & 0.002 \\
\hline
\end{tabular}

a) Minimum cytotoxic concentration was determined on Vero cells. $b$ ) Both isoniazid and ethambutol were reported to be non-toxic at $62.5 \mu \mathrm{g} / \mathrm{mL}$ (equivalent to $455.74 \mu \mathrm{M}$ for isoniazid and $305.91 \mu \mathrm{M}$ for ethambutol) on Vero cells. ${ }^{46)} c$ ) Antituberculosis activity prediction ( $P a$ : probability of activity ; $P i$ : probability of inactivity). 
1,3,4-thiadiazole ring were found to be active in varying levels. Three compounds $(\mathbf{1 1}, \mathbf{1 5}$, and 19) from this series can be distinguished from others by their promising activity profiles by their MIC values comparable to ethambutol. Compounds 11 and 19 were appreciated as the most active representatives with the MIC values of 10.96 and $11.48 \mu \mathrm{M}$, respectively, whereas compound 19 was confirmed to possess higher selectivity than compound 11. Compound $\mathbf{1 5}$ was shown to inhibit M. tuberculosis $\mathrm{H}_{37} \mathrm{Rv}$ strain with the MIC values of $17.81 \mu \mathrm{M}$. Except for 11, 15 and 19, antituberculosis activity of the other compounds were observed between $33.14-178.56 \mu \mathrm{M}$. The compounds 9, 10, 12, 17, 18, 20 with MIC values between 33.14 and $48.42 \mu \mathrm{M}$ are assumed to possess mild antituberculosis activity; and the compounds 6-8, 13, 14, 16 with MIC values greater than $70 \mu \mathrm{M}$ are considered as weakly active against M. tuberculosis $H 37 R v$ strain.

The nature of the substituents on either 1,3,4-thiadiazole $\left(R_{1}\right)$ and thiourea $\left(R_{2}\right)$ was found to affect the activity of the compounds 5-20. Introduction of 4-fluorophenyl substitution on $\mathrm{N}^{3}$ of thiourea moiety yielded the most selective activity (compound 19). Replacing 4-fluorophenyl substitution on $\mathrm{N}^{3}$ of thiourea moiety by 4-chloro-3-trifluoromethylphenyl moiety (compound 20) reduced the activity by 3.2-fold as compared to lead 19. 5-(4-Chlorophenyl)-1,3,4-thiadiazole and 5-(4-fluorophenyl)-1,3,4-thiadiazole were introduced to $\mathrm{N}^{1}$ of thiourea moiety in order to obtain the optimal substitution pattern, consequently 5-(4-fluorophenyl)-1,3,4-thiadiazole moiety seemed to contribute more to the antituberculosis activity than the others.

Active compounds $\mathbf{1 5}$ and $\mathbf{1 9}$ were observed to be non-toxic at $100 \mu \mathrm{M}$, whereas compound $\mathbf{1 1}$ showed toxicity at $\geq 20 \mu \mathrm{M}$. Standard drugs, isoniazid and ethambutol were reported to be non-toxic up to $62.5 \mu \mathrm{g} / \mathrm{mL}$ (equivalent to $455.7 \mu \mathrm{M}$ for isoniazid and $305.91 \mu \mathrm{M}$ for ethambutol) on Vero cells. ${ }^{46)}$ In another work, $\mathrm{IC}_{50}$ values of isoniazid and ethambutol were reported to be higher than 455.7 and $225.4 \mu \mathrm{M}$, respectively. ${ }^{47)}$ Thus, isoniazid and ethambutol appeared as safer antituberculosis agents compared to compounds 11, 15 and 19.

Antibacterial Activity The antibacterial activity of compounds 5-20 except for $\mathbf{6}$ and $\mathbf{1 1}$ was tested against Staphylococcus aureus, Escherichia coli, Bacillus subtilis, Klebsiella pneumoniae, Pseudomonas aeruginosa, Staphylococcus epidermidis and Candida albicans. The MIC was determined by a micro well dilution method (Table 2). Compounds 12 and 14 were found as the most active compounds with the MIC values of 0.19 and $0.23 \mu \mathrm{g} / \mu \mathrm{L}$ against $B$. subtilis. The other compounds were not found active against specifically and significantly active against bacteria mentioned above.

Depending on antituberculosis and antibacterial activity evaluation results we may propose that our compounds are selectively active against $M$. tuberculosis $H_{37} R v$ strain.

Antiviral Activity and Cytotoxicity Studies Thiourea derivatives 5-20 were also evaluated for their broad spectrum antiviral activity against a wide range of DNA and RNA viruses. For each compound, the MIC and the minimal cytotoxic concentration (MCC) or the $50 \%$ cytotoxic concentration $\left(\mathrm{CC}_{50}\right)$ were obtained. Anti-HIV activity and cytotoxicity data were obtained with the synthesized compounds 5-20 using the strains HIV-1 (IIIB) and HIV-2 (ROD) in an MT-4/3-(4,5dimethylthiazol-2-yl)-2,5-diphenyltetrazolium bromide (MTT) based assay. None of the synthesized compounds showed any specific activity against HIV-1 $\left(\mathrm{III}_{\mathrm{B}}\right.$ ) or HIV-2 (strain ROD) in MT-4 cells. The compounds were also evaluated for in vitro antiviral activity against herpes simplex virus [HSV-1 (strain $\mathrm{KOS})$, thymidine kinase deficient $\left(\mathrm{TK}^{-}\right)$strain of $\mathrm{HSV}-1$ resistant to acyclovir $\left.\left(\mathrm{ACV}^{\mathrm{r}}\right), \mathrm{HSV}-2(\mathrm{G})\right]$, vaccinia virus $(\mathrm{VV})$ and vesicular stomatitis virus (VSV) in HEL cell cultures ; VSV, Coxsackie virus B4 and respiratory syncytial virus (RSV) in HeLa cell cultures ; Parainfluenza-3 virus, Reovirus-1, Sindbis virus, Coxsackie virus B4 and Punta Toro virus in Vero cell cultures; influenza A (H1N1, H3N2) influenza B virus in Madin-Darby canine kidney (MDCK) cell cultures; feline coronavirus (FIPV) and feline herpes virus in CRFK cell cultures.

As a result of antiviral screening of 5-20, none of the evaluated compounds showed specific antiviral effects (i.e., minimal antivirally effective concentration $>5$-fold lower than minimal cytotoxic concentration) against any of the viruses examined (data not shown).

Prediction of Drug-Likeness and Absorption, Distribution, Metabolism, and Excretion (ADME) Properties of 5-20 In the development of new drug candidates intended for oral use, oral bioavailability and proper drug delivery are considered to play an important role. ${ }^{48}$ About one-third of drug candidates fail during development due to their poor pharmacokinetic profiles. ${ }^{49)}$ As an ADME property, a low and

Table 2. In Vitro Antibacterial and Antifungal Activity of Compounds 5-20 (MIC in $\mu \mathrm{g} / \mu \mathrm{L}$ )

\begin{tabular}{|c|c|c|c|c|c|c|c|}
\hline Compd ID & E. coli & S. aureus & B. subtilis & K. pneumoniae & P. aeruginosa & S. epidermidis & C. albicans \\
\hline 5 & 1.29 & 0.64 & 1.29 & 1.29 & 1.29 & 1.29 & 1.29 \\
\hline 7 & 1.74 & 1.74 & 1.74 & $>3.48$ & 1.74 & 1.74 & 1.74 \\
\hline 8 & $>3.05$ & 1.53 & 1.53 & 1.53 & 1.53 & 1.53 & 1.53 \\
\hline 9 & 1.35 & 2.70 & 1.35 & 1.35 & 1.35 & 1.35 & 0.68 \\
\hline 10 & 3.73 & 3.73 & 3.73 & 3.73 & 3.73 & 3.73 & 3.73 \\
\hline 12 & 1.49 & 0.74 & 0.19 & 1.49 & 1.49 & 0.74 & 1.49 \\
\hline 13 & 1.68 & 1.68 & 1.68 & 1.68 & 3.35 & 1.68 & 3.35 \\
\hline 14 & 1.80 & 1.80 & 0.23 & 3.60 & 0.90 & 0.90 & 1.80 \\
\hline 15 & 1.73 & 3.73 & 0.86 & 3.45 & 1.73 & 3.73 & 1.73 \\
\hline 16 & 1.86 & 3.73 & 3.73 & 3.73 & 1.86 & 0.93 & 3.73 \\
\hline 17 & 1.78 & $>3.55$ & $>3.55$ & 3.55 & 1.78 & $>3.55$ & 1.78 \\
\hline 18 & $>2.90$ & $>2.90$ & $>2.90$ & $>2.90$ & $>2.90$ & $>2.90$ & $>2.90$ \\
\hline 19 & $>3.48$ & $>3.48$ & $>3.48$ & $>3.48$ & $>3.48$ & $>3.48$ & $>3.48$ \\
\hline 20 & $>2.90$ & $>2.90$ & $>2.90$ & $>2.90$ & $>2.90$ & $>2.90$ & $>2.90$ \\
\hline
\end{tabular}


Table 3. Predicted ADME, Lipinski Parameters and Molecular Properties of the Synthesized Compounds 5-20 ${ }^{a}$

\begin{tabular}{|c|c|c|c|c|c|c|c|c|c|}
\hline Compd ID & MW & Volume & TPSA & $\% \mathrm{ABS}$ & $n$-ROTB & $n-\mathrm{ON}$ & $n$-OHNH & $m i \log P$ & $n$ Violations \\
\hline 5 & 381.958 & 323.608 & 53.076 & 91 & 7 & 5 & 2 & 4.237 & 0 \\
\hline 6 & 374.922 & 309.065 & 49.838 & 92 & 7 & 4 & 2 & 5.103 & 1 \\
\hline 7 & 409.367 & 322.601 & 49.838 & 92 & 7 & 4 & 2 & 5.781 & 1 \\
\hline 8 & 374.878 & 294.445 & 66.909 & 86 & 5 & 5 & 2 & 4.333 & 0 \\
\hline 9 & 346.868 & 275.462 & 49.838 & 92 & 5 & 4 & 2 & 4.360 & 0 \\
\hline 10 & 371.878 & 292.321 & 73.630 & 84 & 5 & 5 & 2 & 4.115 & 0 \\
\hline 11 & 364.858 & 280.393 & 49.838 & 92 & 5 & 4 & 2 & 4.523 & 0 \\
\hline 12 & 482.862 & 338.057 & 49.838 & 92 & 7 & 4 & 2 & 6.078 & 1 \\
\hline 13 & 395.34 & 305.559 & 49.838 & 92 & 5 & 4 & 2 & 5.414 & 1 \\
\hline 14 & 449.31 & 320.295 & 49.838 & 92 & 6 & 4 & 2 & 5.861 & 1 \\
\hline 15 & 449.31 & 320.295 & 49.838 & 92 & 6 & 4 & 2 & 5.861 & 1 \\
\hline 16 & 358.423 & 285.841 & 66.909 & 86 & 5 & 5 & 2 & 3.818 & 0 \\
\hline 17 & 330.413 & 266.857 & 49.838 & 92 & 5 & 4 & 2 & 3.845 & 0 \\
\hline 18 & 355.423 & 283.717 & 73.63 & 84 & 5 & 5 & 2 & 3.600 & 0 \\
\hline 19 & 348.403 & 271.788 & 49.838 & 92 & 5 & 4 & 2 & 4.009 & 0 \\
\hline 20 & 432.855 & 311.691 & 49.838 & 92 & 6 & 4 & 2 & 5.347 & 1 \\
\hline
\end{tabular}

a) \% ABS: Percentage of absorption, TPSA: topological polar surface area, $n$-ON: number of hydrogen bond acceptors, $n$-OHNH: number of hydrogen bond donors, $n$ ROTB: number of rotatable bonds. Calculations were performed using Molinspiration online property calculation toolkit (http://www.molinspiration.com).

variable bioavailability is the major reason to quit further development of the drug candidate. ${ }^{50)}$ Therefore, a computational study for prediction of ADME properties of the molecules was performed by determination of lipophilicity, topological polar surface area (TPSA), absorption (\% ABS) and simple molecular descriptors used by Lipinski in formulating his "rule of five."51) Calculations were performed using Molinspiration online property calculation toolkit. ${ }^{52)}$ Table 3 represents a calculated percentage of absorption ( $\% \mathrm{ABS})$, topological polar surface area (TPSA) and Lipinski parameters of the compounds 5-20. Percentage of absorption (\% ABS) was estimated using the equation: $\% \mathrm{ABS}=109-(0.345 \times \mathrm{TPSA})$, according to Zhao et al. ${ }^{53)}$ TPSA was also calculated using Molinspiration online property calculation toolkit according to the fragment-based method of Ertl et al. ${ }^{54)}$ Polar surface area, together with lipophilicity, is an important property of a molecule in transport across biological membranes. Too high TPSA values give rise to a poor bioavailability and absorption of a drug. According to the above criterions, calculated percentages of absorption for compounds 5-20 ranged between 84 and 92\%.

Number of hydrogen bond donors was constant for all of the compounds, and number of hydrogen bond acceptors varied 4 to 5 . Investigation of Lipinski parameters of the synthesized compounds showed that all heterocyclic thiourea derivatives of 2-amino-1,3,4-thiadiazoles, might be considered as drug-like candidates for novel anti-tuberculosis agents, as they obeyed the rule of five without violating more than one of them.

There were no direct correlations observed between simple molecular properties such as $\log P$ and anti-tuberculosis activity. Nevertheless, it was notable that two most active derivatives (11 and 19) among compounds 5-20 with 4-fluorophenyl substitution at $\mathrm{R}_{2}$ position, had good calculated absorption values and zero violations to Lipinski rule of five.

\section{Osiris Calculations}

Prediction of Toxicity, Solubility, Drug-Likeness and Drug Score for Compounds 5-20

Potential toxicity, solubility, and drug-like properties (solubility, drug-likeness, and drug score) of the thioureas 5-20 were estimated by Osiris Property Explorer. ${ }^{55,56)}$ The predicted risks include mutagenic, tumorigenic, irritant and reproductive toxicity (Table 4). The property predictor detects fragments within a given molecule as an indicator for a potential toxicity risk. Toxicity risk alerts are used as indicators showing that the investigated structure may be harmful concerning the specified toxicity risk. From the findings given in Table 4, it can be claimed that the target compounds 5-20 are expected to be free of mutagenic, tumorigenic, irritating (except 14) effects and reproductive toxicity (except 8 and 16). Water solubility of a drug candidate significantly influences its absorption and distribution characteristics. According to the Osiris database, more than $80 \%$ of the traded drugs have predicted solubility values greater than -4 . As shown in Table 4, the synthesized thioureas 5-20 exhibited solubility values between -2.95 and -6.48 .

Drug-likeness can be described as a complicated balance of diverse molecular properties and structural characteristics indicating whether a given molecule is similar to the common drugs or not. ${ }^{57)}$ Osiris property explorer was also utilized to calculate the fragment-based drug-likeness of the synthesized compounds. A positive value demonstrates that the designed compound contains predominatly fragments which are commonly available in traded drugs.

Results presented in Table 4 indicates that majority of 1,3,4-thiadiazolyl thioureas $\mathbf{5 - 2 0}$ have positive drug-likeness values. The drug score unites porperties such as drug-likeness, $c \log P$, solubility, molecular weight, and toxicity risks in one useful parameter that may be used to estimate the compound's whole potential to qualify for a drug. ${ }^{55)}$ A drug score of 0.5 or higher makes the compound a promising lead for further development to reach safe and efficient drugs. The overall drug score values for the thioureas 5-20 were calculated and compared to those of thiacetazone and isoxyl (Table 4). Compounds 5, 6, 9, 11, 17 and 19 possess good drug score values. Of these, compounds $\mathbf{1 1}$ and $\mathbf{1 9}$ had also good druglikeness values and antituberculosis activity.

PASS-Assisted Antituberculosis Activity Prediction

The experimental testing of dozens of millions of organic 
Table 4. Estimation of Toxicity, Solubility, Drug-Likeness and Drug Score for Thioureas 5-20

\begin{tabular}{|c|c|c|c|c|c|c|c|}
\hline \multirow{2}{*}{ Compound } & \multicolumn{4}{|c|}{ Toxicity risks $^{a)}$} & \multirow{2}{*}{ Solubility } & \multirow{2}{*}{ Drug-likeness } & \multirow{2}{*}{ Drug score } \\
\hline & Mutagenicity & Tumorigenicity & Irritation & Reproductive & & & \\
\hline 5 & - & - & - & - & -2.95 & 5.43 & 0.82 \\
\hline 6 & - & - & - & - & -4.90 & 4.62 & 0.55 \\
\hline 7 & - & - & - & - & -5.63 & 4.48 & 0.42 \\
\hline 8 & - & - & - & ++ & -4.91 & 4.58 & 0.35 \\
\hline 9 & - & - & - & - & -4.97 & 2.26 & 0.55 \\
\hline 10 & - & - & - & - & -5.74 & -3.10 & 0.26 \\
\hline 11 & - & - & - & - & -5.28 & 2.49 & 0.51 \\
\hline 12 & - & - & - & - & -6.52 & -18.50 & 0.14 \\
\hline 13 & - & - & - & - & -6.05 & 3.48 & 0.39 \\
\hline 14 & - & - & ++ & - & -6.48 & -4.23 & 0.10 \\
\hline 15 & - & - & - & - & -6.48 & -4.16 & 0.16 \\
\hline 16 & - & - & - & ++ & -4.49 & 2.90 & 0.39 \\
\hline 17 & - & - & - & - & -4.55 & 0.53 & 0.54 \\
\hline 18 & - & - & - & - & -5.32 & -4.83 & 0.29 \\
\hline 19 & - & - & - & - & -4.86 & 1.93 & 0.57 \\
\hline 20 & - & - & - & - & -6.06 & -4.49 & 0.19 \\
\hline Thiacetazone & ++ & - & - & - & -3.24 & 4.23 & 0.53 \\
\hline Isoxyl & - & - & + & - & -5.76 & 1.23 & 0.26 \\
\hline
\end{tabular}

a) -: low risk; +: moderate risk; ++ : high risk.

compounds for thousands biological activities is obviously unachievable, mandating the need for computer methods for the search and optimization of new pharmacologically active compounds. ${ }^{58)}$ Structure-based drug design and ligand-based drug design are the two computer-based approaches of drug design which are currently being used. ${ }^{59)}$ Anti-tuberculosis activity of our thiourea based compounds 5-20 was predicted by using the online version of PASS (Prediction of Activity Spectra for Substances) program. ${ }^{60)}$ PASS online is a software that enables to predict biological activity profile of drug-like organic compounds (with a molecular mass range between 50 and $1250 \mathrm{Da}$ ) according to their chemical structures for more than 4000 types of biological activity including pharmacological effects, mechanisms of actions, interactions with biotransformation enzymes, side effects and toxic properties. The prediction is based on analysis of the structure-activity relationships in the training set containing information on the structure and biological activity of more than 300000 organic compounds. ${ }^{61)}$ The chemical structure is represented by the set of descriptors of multilevel neighborhoods of atoms (MNA). ${ }^{62)}$ The average prediction accuracy calculated by the leave-oneout cross-validation procedure for the whole training set and for all represented in it types of biological activity is about $95 \%{ }^{63)}$

The PASS online program provides 'two parameters as a list of predicted types of activity: the probability "to be active" $(P a)$ and the probability "to be inactive" $(P i)$, which vary from zero to one.' The possibility of experimentally determining a certain kind of activity increases with rising value of $\mathrm{Pa}$ and decreasing value of $P i{ }^{61)}$ In analyzing a predicted activity spectrum, if those types of activity are selected, for which $P a>0.9$, the expected probability to find inactive compounds in the selected set is very low, but we risk missing about $90 \%$ of actually active compounds. ${ }^{61)}$ If only compounds with $P a>0.8$ are chosen, the probability to find inactive compounds is still low, but about $80 \%$ of active compounds are missed etc.
It is also worth emphasizing that the probability $\mathrm{Pa}$ primarily projects the resemblance of the structure of a given molecule to the structures of the most characteristic active molecules in the corresponding subset of the training set. Thus, as a rule, there is no direct correlation of the $P a$ values with quantitative activity characteristics. Essentially, each selection is always a compromise between the preferred novelty of tested molecule and risk to obtain the negative result in biological screening.

Another important aspect of interpreting the prediction results is related to novelty of the analyzed compound. If we limit ourselves only to activity types predicted with the highest values of $\mathrm{Pa}$, the compounds selected by the prediction may prove to be analogs of known pharmacological agents. For example, when $P a>0.7$, the chances of finding experimental activity are rather high but the compounds found may be close structural analogs of known drugs. If we select in the range $0.5<P a<0.7$, the chances for detecting experimental activity will be lower but the compounds will be less similar to known pharmaceutical agents. For $P i<P a<0.5$, the chances of detecting experimental activity will be even lower but if the prediction is confirmed, the compound found may prove a parent compound for a new chemical class for the biological activity examined. ${ }^{61)}$

There are many examples of successful use of PASS approach for finding new pharmacological agents. ${ }^{63-69)}$ Antituberculosis activity were predicted for our compound set 5-20 within the range of $0.364<P a<0.684$. Although no direct correlation were observed between $P a$ values and MIC values, it was notable that most active three compounds had good $\mathrm{Pa}$ scores $(P a>0.5)$. As expected, INH and ethambutol gave high $P a$ values in the same prediction model.

Molecular Modeling The recent reports on most promising 1,3,4-thiadiazole derivatives with highly potent activity towards Mtb have revealed the target mycobacterial enoyl acyl carrier protein reductase (InhA) due to assessment of InhA inhibition values of the mentioned compounds. ${ }^{24,25)}$ We were 




Fig. 3. Superimposition of Docked Pose of the Reported Reference Inhibitor (Yellow) to the Original Pose of the Reference Inhibitor (Red)

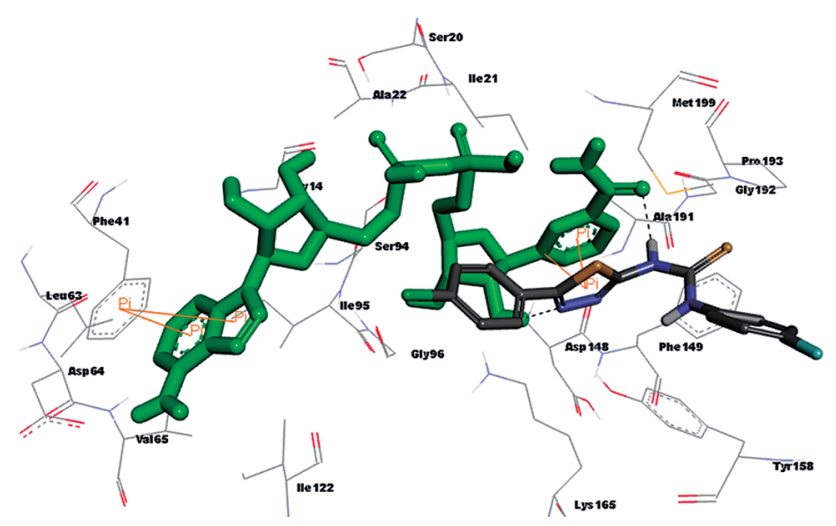

Compound 11

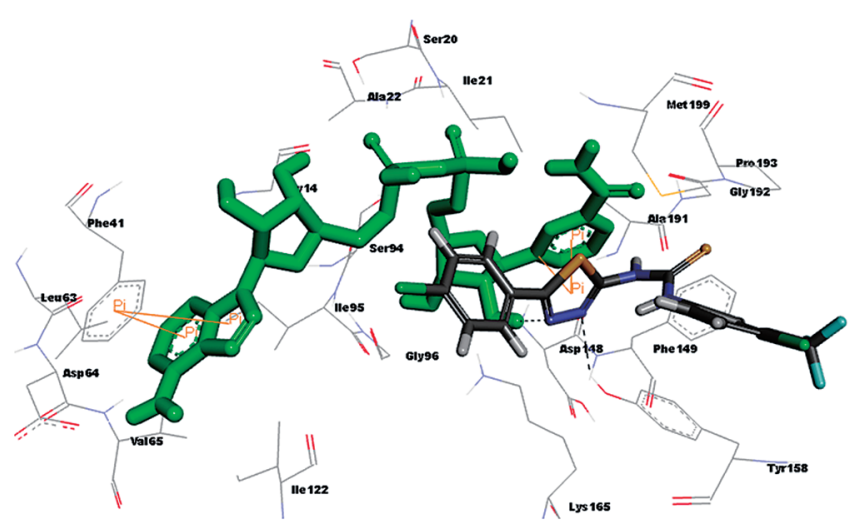

Compound 15

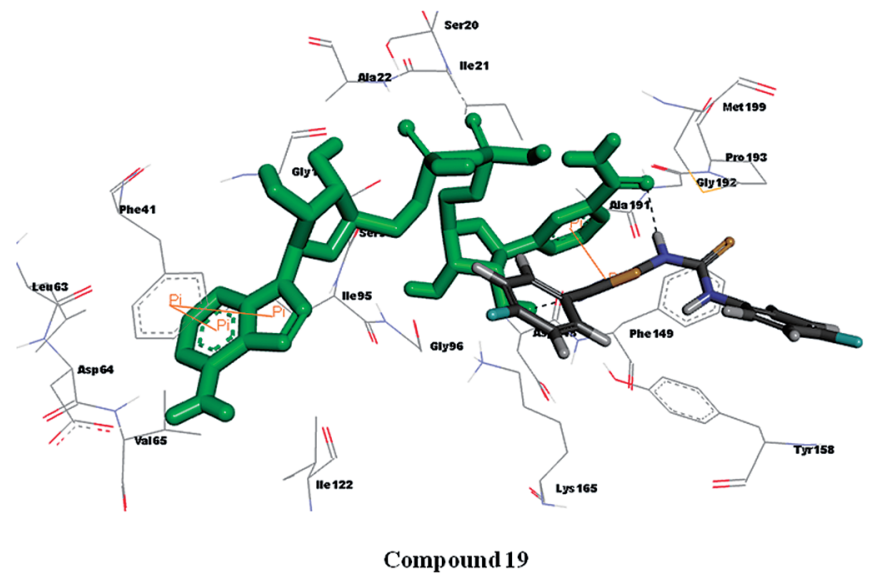

Fig. 4. Binding Analysis of Compounds 11, 15 and $\mathbf{1 9}$ in the Active Site of InhA Protein

also inspired by the experimental MIC data that are generally in consistent with the InhA inhibitory activities of 1,3,4-thiadiazole derivatives to perform molecular docking study. ${ }^{24,25)}$ In order to further rationalize the biological results of our compounds, we perform molecular docking studies on se- lected active (compounds 11, 15, 19) and inactive derivatives (compounds 6 and 17) with InhA of M. tuberculosis.

The crystal structure of MTB InhA complexed with reference inhibitor 1-cyclohexyl- $N$-(3,5-dichlorophenyl)-5-oxopyrrolidine-3-carboxamide (PDB:2H7M) having resolution of 

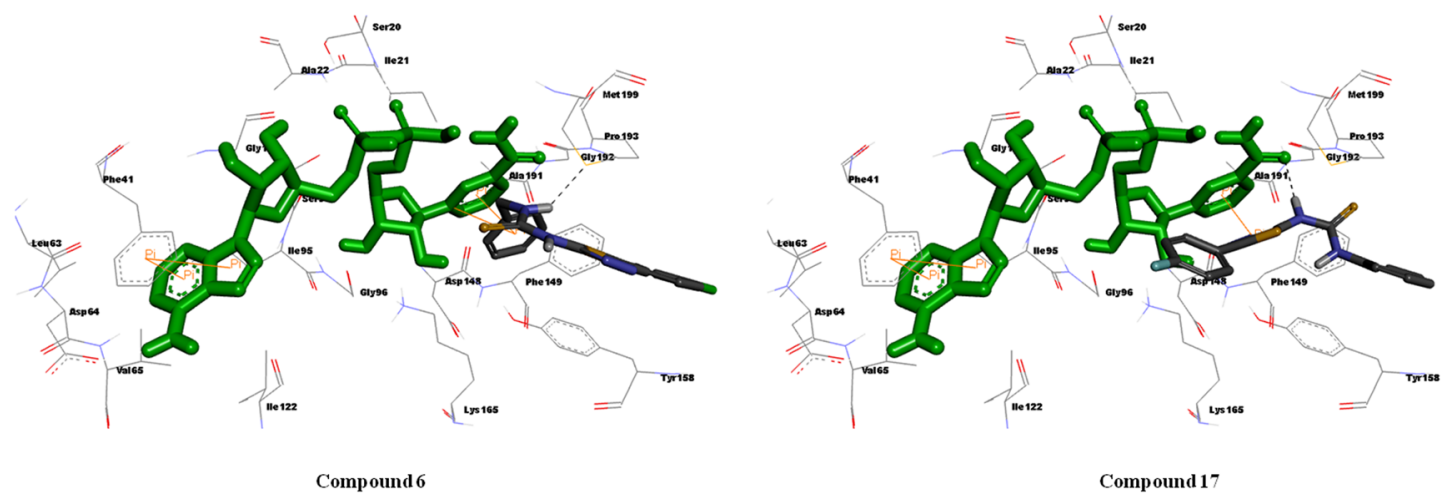

Fig. 5. Binding Analysis of Compounds $\mathbf{6}$ and $\mathbf{1 7}$ in the Active Site of InhA Protein

$1.62 \AA$ was selected and docking results obtained with Glide, version 5.7, Schrodinger, LLC, New York, NY, 2012. Analysis of the crystal structure of $2 \mathrm{H} 7 \mathrm{M}$ revealed that the reference inhibitor in the InhA active site formed hydrogen-bonding network between Tyr158, enzyme active site residues, and the oxidized form of nicotinamide adenine dinucleotide $\left(\mathrm{NAD}^{+}\right)$ cofactor that probably served as the key feature that governed the orientation of the compound within the active site. Dual hydrogen bonding network was involved with the oxygen atom on the pyrrolidine carbonyl group, InhA catalytic residue Tyr158, and the $\mathrm{NAD}^{+}$. This hydrogen bonding network seemed to be a conserved feature among all the InhA-inhibitor complexes identified so far. The reference 1-cyclohexyl- $N$ (3,5-dichlorophenyl)-5-oxopyrrolidine-3-carboxamide was redocked with the active site residues of the MTB InhA to validate the active site cavity. The ligand exhibited highest Glide score of $-8.02 \mathrm{kcal} / \mathrm{mol}$ and was found in the vicinity of amino acids Tyr158, Phe149, Met199, Ile215, Pro156, Leu218, Met155, Ala211, Ile202, Met103, Leu207, Ala157, Met161, Phe97, Met98, Gly96, Gly104 and Lys165 residues. The redocking results showed that the compound exhibited similar interactions as that of the original crystal structure with root-mean-square deviation (RMSD) of $0.87 \AA$ suggesting reliability of the docking method. The superimposition of Glide docked conformation of co-crystal with co-crystal of $2 \mathrm{H} 7 \mathrm{M}$ is shown in Fig. 3.

Binding Analysis of Active Compounds (11, 15 and 19)

The compounds 11, 15 and 19 with chloro and fluoro group at $\mathrm{R}_{1}$ position and 4-fluorophenyl, 4-chloro-3-(trifluoromethyl)phenyl and 4-fluorophenyl groups at $\mathrm{R}_{2}$ substituent's, showed good MIC. All the three compounds were docked in the binding site of InhA protein and were displayed good docking scores in the range of -7.12 to $-7.83 \mathrm{kcal} / \mathrm{mol}$. The predicted binding pose of the active compounds $(\mathbf{1 1}, 15$ and 19) suggested that the observed potency may be due to the extensive hydrophobic interactions predicted to be formed with the side chains of Met199, Leu218, Met155, Pro156, Ala157, Ile202, Met103, Phe149 and Met161 along with hydrogen bonding interactions with the ribose hydroxyl group of $\mathrm{NAD}^{+}$(Fig. 4). Among these three compounds, only compound $15\left[\mathrm{R}_{1}: \mathrm{Cl}\right.$; $\mathrm{R}_{2}$ : 4-chloro-3-(trifluoromethyl)phenyl] was observed to interact with side chain of Tyr158 via hydrogen bonding between nitrogen atom at 3 rd position of 1,3,4-thiadiazole and phenolic group of tyrosine. Apart from these interactions, all the three compounds were further stabilized by $P i-P i$ interactions. From the docking results, it was evident that the formation of hydrogen bonds with hydroxyl group of $\mathrm{NAD}^{+}$along with hydrophobic interactions with the active site were predicted to be the most crucial factors affecting the inhibitory potency of these compounds.

Binding Analysis of Inactive Compounds (6 and 17)

Ligand binding analysis of one of the less active derivatives from this subset (6 and 17) showed hydrophobic interactions with some hydrophobic amino acid residues. However, the orientation in the active site cavity of InhA pushed the chloro group in compound $\mathbf{6}$ and phenyl group in compound $\mathbf{1 7}$ away from the cavity, which might be the reason for its lesser activity. In silico analysis of both the compounds indicated that the molecule oriented in a different manner than that of other active derivatives and failed to demonstrate any interaction with Tyr158 residue as well as with $\mathrm{NAD}^{+}$resulting in less activity in M. tuberculosis strains (Fig. 5). This is well supported by the low docking score of -5.57 and $-6.20 \mathrm{kcal} / \mathrm{mol}$.

\section{CONCLUSION}

As a result of antiviral, antibacterial and antituberculosis activity screening results, it can be concluded that 1,3,4-thiadiazolyl thiourea derivatives 5-20 designed in this study had selective action on M. tuberculosis H37Rv. Cytotoxicity results on Vero cell line showed that three derivatives which showed the highest activity had selectivity indices between 1.8 and 8.7. Compounds $\mathbf{1 1}, \mathbf{1 5}$ and $\mathbf{1 9}$ have been identified as useful leads for further development in terms of better solubility, ADME properties and toxicity profile. Molecular docking studies on selected active compounds 11, 15 and 19 displayed good docking scores in the range of -7.12 to $-7.83 \mathrm{kcal} / \mathrm{mol}$. Studies on optimized new sets of thiadiazolyl thiourea derivatives are in progress at our laboratories.

Acknowledgments This work was supported by the Research Fund of Marmara University, project number: SAG-BGS-290506-0073 (approved: 29.05.2006-completed: 29.05.2009). This work was partly presented in oral presentation form at the Third International Meeting on Pharmacy \& Pharmaceutical Sciences (IMPPS-3), İstanbul, Turkey, 9-12 June 2010 and it was also presented in poster presentation form at the Fourth International Meeting on Pharmacy \& Pharmaceutical Sciences (IMPPS-4), İstanbul, Turkey, 18-21 September 2014. The authors are grateful to Dr. Jürgen Gross from the Institute of Organic Chemistry, University of Heidelberg, for his generous help on obtaining HR-MS (FAB and 
ESI) analyses in this project.

Conflict of Interest The authors declare no conflict of interest.

\section{REFERENCES}

1) Daniel TM. The history of tuberculosis. Respir. Med., 100, 1862 1870 (2006).

2) "WHO Global tuberculosis report 2013.”: 〈http://apps.who.int/iris/ bitstream/10665/91355/1/9789241564656_eng.pdf?ua=1), cited 18 July, 2015.

3) Hasan R. Drug resistant tuberculosis: Challenges of urbanization. Int. J. Mycobacteriol., 3, 79-81 (2014).

4) Perdigão J, Macedo R, Silva C, Machado D, Couto I, Viveiros M, Jordao L, Portugal I. From multidrug-resistant to extensively drugresistant tuberculosis in Lisbon, Portugal: the stepwise mode of resistance acquisition. J. Antimicrob. Chemother., 68, 27-33 (2013).

5) Dobrikov GM, Valcheva V, Nikolova Y, Ugrinova I, Pasheva E, Dimitrov V. Efficient synthesis of new $(R)$-2-amino-1-butanol derived ureas, thioureas and acylthioureas and in vitro evaluation of their antimycobacterial activity. Eur. J. Med. Chem., 63, 468-473 (2013).

6) Van Poecke S, Munier-Lehmann H, Helynck O, Froeyen M, Van Calenbergh S. Synthesis and inhibitory activity of thymidine analogues targeting Mycobacterium tuberculosis thymidine monophosphate kinase. Bioorg. Med. Chem., 19, 7603-7611 (2011).

7) Küçükgüzel I, Küçükgüzel SG, Rollas S, Kiraz M. Some 3-thioxo/ alkylthio-1,2,4-triazoles with a substituted thiourea moiety as possible antimycobacterials. Bioorg. Med. Chem. Lett., 11, 1703-1707 (2001).

8) Küçükgüzel I, Tatar E, Küçükgüzel SG, Rollas S, De Clercq E. Synthesis of some novel thiourea derivatives obtained from 5-[(4-aminophenoxy)methyl]-4-alkyl/aryl-2,4-dihydro-3H-1,2,4triazole-3-thiones and evaluation as antiviral/anti-HIV and antituberculosis agents. Eur. J. Med. Chem., 43, 381-392 (2008).

9) Sriram D, Yogeeswari P, Madhu K. Synthesis and in vitro antitubercular activity of some 1-[(4-sub)phenyl]-3-(4-\{1-[(pyridine-4carbonyl)hydrazono]ethyl\}phenyl)thiourea. Bioorg. Med. Chem. Lett., 16, 876-878 (2006).

10) Sriram D, Yogeeswari $P$, Dinakaran M, Thirumurugan R. Antimycobacterial activity of novel 1-(5-cyclobutyl-1,3-oxazol-2-yl)-3(sub)phenyl/pyridylthiourea compounds endowed with high activity toward multidrug-resistant Mycobacterium tuberculosis. J. Antimicrob. Chemother., 59, 1194-1196 (2007).

11) Bhowruth V, Brown AK, Reynolds RC, Coxon GD, Mackay SP, Minnikin DE, Besra GS. Symmetrical and unsymmetrical analogues of isoxyl; active agents against Mycobacterium tuberculosis. Bioorg. Med. Chem. Lett., 16, 4743-4747 (2006).

12) Baulard AR, Betts JC, Engohang-Ndong J, Quan S, McAdam RA, Brennan PJ, Locht C, Besra GS. Activation of the pro-drug ethionamide is regulated in mycobacteria. J. Biol. Chem., 275, 2832628331 (2000).

13) DeBarber AE, Mdluli K, Bosman M, Bekker LG, Barry CE 3rd. Ethionamide activation and sensitivity in multidrug-resistant $\mathrm{My}$ cobacterium tuberculosis. Proc. Natl. Acad. Sci. U.S.A., 97, $9677-$ 9682 (2000).

14) Korduláková J, Janin YL, Liav A, Barilone N, Dos Vultos T, Rauzier J, Brennan PJ, Gicquel B, Jackson M. Isoxyl activation is required for bacteriostatic activity against Mycobacterium tuberculosis. Antimicrob. Agents Chemother., 51, 3824-3829 (2007).

15) Wang C, Hickey AJ. Isoxyl particles for pulmonary delivery: in vitro cytotoxicity and potency. Int. J. Pharm., 396, 99-104 (2010).

16) Kandemirli F, Shvets N, Unsalan S, Küçükgüzel I, Rollas S, Kovalishyn V, Dimoglo A. The structure-antituberculosis activity relationships study in a series of 5-(4-aminophenyl)-4-substitut-
ed-2,4-dihydro-3H-1,2,4-triazole-3-thione derivatives. A combined electronic-topological and neural networks approach. Med. Chem., 2, 415-422 (2006).

17) Revelant G, Gadais C, Mathieu V, Kirsch G, Hesse S. Synthesis and antiproliferative studies of 5-aryl-2-(3-thienylamino)-1,3,4-thiadiazoles. Bioorg. Med. Chem. Lett., 24, 2724-2727 (2014).

18) Zoumpoulakis P, Camoutsis Ch, Pairas G, Soković M, Glamočlija J, Potamitis C, Pitsas A. Synthesis of novel sulfonamide-1,2,4triazoles, 1,3,4-thiadiazoles and 1,3,4-oxadiazoles, as potential antibacterial and antifungal agents. Biological evaluation and conformational analysis studies. Bioorg. Med. Chem., 20, 1569-1583 (2012).

19) Liesen AP, de Aquino TM, Carvalho CS, Lima VT, de Araújo JM, de Lima JG, de Faria AR, de Melo EJT, Alves AJ, Alves EW, Alves AQ, Góes AJS. Synthesis and evaluation of anti-Toxoplasma gondii and antimicrobial activities of thiosemicarbazides, 4-thiazolidinones and 1,3,4-thiadiazoles. Eur. J. Med. Chem., 45, 3685-3691 (2010).

20) Liu XH, Shi YX, Ma Y, Zhang CY, Dong WL, Pan L, Wang BL, Li BJ, Li ZM. Synthesis, antifungal activities and 3D-QSAR study of $N$-(5-substituted-1,3,4-thiadiazol-2-yl)cyclopropanecarboxamides. Eur. J. Med. Chem., 44, 2782-2786 (2009).

21) Küçükgüzel SG, Küçükgüzel I, Tatar E, Rollas S, Sahin F, Güllüce M, De Clercq E, Kabasakal L. Synthesis of some novel heterocyclic compounds derived from diflunisal hydrazide as potential anti-infective and anti-inflammatory agents. Eur. J. Med. Chem., 42, 893-901 (2007).

22) Abdel Rahman DE, Mohamed KO. Synthesis of novel 1,3,4-thiadiazole analogues with expected anticancer activity. Der. Pharma. Chem., 6, 323-335 (2014).

23) Mishra RM, Singh DV, Wahab A, Mishra AR. Synthesis and fungitoxicity of 1,2,4-triazolo[3,2-b][1,3,4]thiadiazole-6-thiones. Pestic. Res. J., 16, 7-10 (2004).

24) Küçükgüzel I, Satılmış G, Gurukumar KR, Basu A, Tatar E, Nichols DB, Talele TT, Kaushik-Basu N. 2-Heteroarylimino-5-arylidene4-thiazolidinones as a new class of non-nucleoside inhibitors of HCV NS5B polymerase. Eur. J. Med. Chem., 69, 931-941 (2013).

25) Çakır G, Küçükgüzel İ, Guhamazumder R, Tatar E, Manvar D, Basu A, Patel BA, Zia J, Talele TT, Kaushik-Basu N. Novel 4-thiazolidinones as non-nucleoside inhibitors of hepatitis $\mathrm{C}$ virus NS5B RNA-dependent RNA polymerase. Arch. Pharm. (Weinheim), 348, 10-22 (2015).

26) Maresca A, Carta F, Vullo D, Scozzafava A, Supuran CT. Carbonic anhydrase inhibitors. Inhibition of the Rv1284 and Rv3273 betacarbonic anhydrases from Mycobacterium tuberculosis with diazenylbenzenesulfonamides. Bioorg. Med. Chem. Lett., 19, 4929-4932 (2009).

27) Sink R, Sosič I, Živec M, Fernandez-Menendez R, Turk S, Pajk S, Alvarez-Gomez D, Lopez-Roman EM, Gonzales-Cortez C, RullasTriconado J, Angulo-Barturen I, Barros D, Ballell-Pages L, Young RJ, Encinas L, Gobec S. Design, synthesis, and evaluation of new thiadiazole-based direct inhibitors of enoyl acyl carrier protein reductase (InhA) for the treatment of tuberculosis. J. Med. Chem., 58, 613-624 (2015).

28) Shirude PS, Madhavapeddi P, Naik M, Murugan K, Shinde V, Nandishaiah R, Bhat J, Kumar A, Hameed S, Holdgate G, Davies G, McMiken H, Hegde N, Ambady A, Venkatraman J, Panda M, Bandodkar B, Sambandamurthy VK, Read JA. Methyl-thiazoles: a novel mode of inhibition with the potential to develop novel inhibitors targeting InhA in Mycobacterium tuberculosis. J. Med. Chem., 56, 8533-8542 (2013).

29) Ananthan S, Faaleolea ER, Goldman RC, Hobrath JV, Kwong CD, Laughon BE, Maddry JA, Mehta A, Rasmussen L, Reynolds RC, Secrist JA 3rd, Shindo N, Showe DN, Sosa MI, Suling WJ, White EL. High-throughput screening for inhibitors of Mycobacterium tuberculosis H37Rv. Tuberculosis., 89, 334-353 (2009).

30) Foroumadi A, Kargar Z, Sakhteman A, Sharifzadeh Z, Feyzmo- 
hammadi R, Kazemi M, Shafiee A. Synthesis and antimycobacterial activity of some alkyl [5-(nitroaryl)-1,3,4-thiadiazol-2-ylthio]propionates. Bioorg. Med. Chem. Lett., 16, 1164-1167 (2006).

31) Plumitallo A, Cardia MC, Distinto S, DeLogu A, Maccioni E. Synthesis and anti-microbial activity evaluation of some new 1-benzoylisothiosemicarbazides. Il Farmaco., 59, 945-952 (2004).

32) Rajak H, Deshmukh R, Aggarwal N, Kashaw S, Kharya MD, Mishra P. Synthesis of novel 2,5-disubstituted 1,3,4-thiadiazoles for their potential anticonvulsant activity: pharmacophoric model studies. Arch. Pharm. (Weinheim), 342, 453-461 (2009).

33) Tu G, Li S, Huang H, Li G, Xiong F, Mai X, Zhu H, Kuang B, Xu WF. Novel aminopeptidase $\mathrm{N}$ inhibitors derived from 1,3,4-thiadiazole scaffold. Bioorg. Med. Chem., 16, 6663-6668 (2008).

34) Us D, Gürdal E, Berk B, Öktem S, Kocagöz T, Çağlayan B, Aksan Kurnaz I, Demir Erol D. 4H-Pyran-4-one derivatives: leading molecule for preparation of compounds with antimycobacterial potential. Turk. J. Chem., 33, 803-812 (2009).

35) Berk B, Us D, Öktem S, Kocagöz ZT, Çağlayan B, Aksan Kurnaz I, Demir Erol D. Molecular modeling and antimycobacterial studies of Mannich bases: 5-hydroxy-2-methyl-4H-pran-4-ones. Turk. J. Chem., 35, 317-330 (2011).

36) Akgün H, Karamelekoğlu İ, Berk B, Kurnaz I, Sarıbıyık G, Öktem S, Kocagöz T. Synthesis and antimycobacterial activity of some phthalimide derivatives. Bioorg. Med. Chem., 20, 4149-4154 (2012).

37) Gul HI, Sahin F, Gul M, Ozturk S, Yerdelen KO. Evaluation of antimicrobial activities of several mannich bases and their derivatives. Arch. Pharm. (Weinheim), 338, 335-338 (2005).

38) Tatar E, Küçükgüzel SG, Karakuş S, De Clercq E, Andrei G, Snoeck R, Pannecouque C, Öktem-Okullu S, Ünübol N, Kocagöz T, Kalaycı S, Şahin F, Küçükgüzel İ. Synthesis and biological evaluation of some new 1,3,4-thiadiazole and 1,2,4-triazole derivatives from L-methionine as antituberculosis and antiviral agents. Marmara. Pharm. J., 19, 88-102 (2015).

39) George S, Basheer RM, Ram SV, Selvaraj SK, Rajan S, Ravi TK. Design, docking, synthesis and anti E. coli screening of novel thiadiazolo thiourea derivatives as possible inhibitors of Enoyl ACP reductase (FabI) enzyme. Bangladesh J. Pharmacol., 9, 49-53 (2014).

40) Falvo F, Fiebig L, Dreiocker F, Wang R, Armentrout PB, Schäfer M. Fragmentation reactions of thiourea- and urea-compounds examined by tandem MS-, energy-resolved CID experiments, and theory. Int. J. Mass Spectrom., 330-332, 124-133 (2012).

41) Çıkla P, Küçükgüzel SG, Küçükgüzel I, Rollas S, De Clercq E, Pannecouque C, Andrei G, Snoeck R, Şahin F, Bayrak ÖF. Synthesis and evaluation of antiviral, antitubercular and anticancer activities of some novel thioureas derived from 4-aminobenzohydrazide hydrazones. Marmara. Pharm. J., 14, 13-20 (2010).

42) Karakuş S, Küçükgüzel ŞG, Küçükgüzel İ, De Clercq E, Pannecouque C, Andrei G, Snoeck R, Şahin F, Bayrak OF. Synthesis, antiviral and anticancer activity of some novel thioureas derived from $N$-(4-nitro-2-phenoxyphenyl)-methanesulfonamide. Eur. J. Med. Chem., 44, 3591-3595 (2009).

43) Arslan NB, Kazak C, Aydın F. $N$-(4-Nitrobenzoyl)- $N$ '-(1,5-dimethyl-3-oxo-2-phenyl-1H-3(2H)-pyrazolyl)-thiourea hydrate: synthesis, spectroscopic characterization, X-ray structure and DFT studies. Spectrochim. Acta A Mol. Biomol. Spectrosc., 89, 30-38 (2012).

44) Yusof MSM, Jusoh RH, Khairul WM, Yamin BM. Synthesis and characterisation a series of $N$-(3,4-dichlorophenyl)- $N^{\prime}$-(2,3 and 4methylbenzoyl)thiourea derivatives. J. Mol. Struct., 975, 280-284 (2010).

45) Rotondo A, Barresi S, Cusumano M, Rotondo E. Structural and dynamic NMR characterization of $\left[\operatorname{Pd}(\text { bipy })(R \text {-thiourea })_{2}\right]^{2+}$ and $\left[\operatorname{Pd}(\text { phen })(R \text {-thiourea })_{2}\right]^{2+}$ cations. Polyhedron, 45, 23-29 (2012).

46) Yoon YK, Ali MA, Wei AC, Choon TS, Ismail R. Synthesis and evaluation of antimycobacterial activity of new benzimidazole aminoesters. Eur. J. Med. Chem., 93, 614-624 (2015).

47) Sriram D, Yogeeswari P, Dinakaran M, Thirumurugan R. Anti- mycobacterial activity of novel 1-(5-cyclobutyl-1,3-oxazol-2-yl)-3(sub)phenyl/pyridylthiourea compounds endowed with high activity toward multidrug-resistant Mycobacterium tuberculosis. J. Antimicrob. Chemother., 59, 1194-1196 (2007).

48) Hou $\mathrm{T}, \mathrm{Xu} \mathrm{X}$. Recent development and application of virtual screening in drug discovery: an overview. Curr. Pharm. Des., 10, 1011-1033 (2004).

49) van de Waterbeemd $\mathrm{H}$, Gifford E. ADMET in silico modelling: towards prediction paradise? Nat. Rev. Drug Discov., 2, 192-204 (2003).

50) Hou T, Wang J, Zhang W, Xu X. ADME evaluation in drug discovery. 6. Can oral bioavailability in humans be effectively predicted by simple molecular property-based rules? J. Chem. Inf. Model., 47, 460-463 (2007).

51) Lipinski CA, Lombardo F, Dominy BW, Feeney PJ. Experimental and computational approaches to estimate solubility and permeability in drug discovery and development settings. Adv. Drug Deliv. Rev., 46, 3-26 (2001)

52) Bratislava Slovak Republic. "Molinspiration Cheminformatics.": 〈http://www.molinspiration.com/services/properties.html〉, cited 18 July, 2015.

53) Zhao YH, Abraham MH, Le J, Hersey A, Luscombe CN, Beck G, Sherborne B, Cooper I. Rate-limited steps of human oral absorption and QSAR studies. Pharm. Res., 19, 1446-1457 (2002).

54) Ertl P, Rohde B, Selzer P. Fast calculation of molecular polar surface area as a sum of fragment-based contributions and its application to the prediction of drug transport properties. J. Med. Chem., 43, 3714-3717 (2000).

55) Jarrahpour A, Fathi J, Mimouni M, Ben Hadda T, Sheikh J, Chohan $\mathrm{ZH}$, Parvez A. Petra, Osiris and Molinspiration (POM) together as a successful support in drug design: antibacterial activity and biopharmaceutical characterization of some azo Schiff bases. Med. Chem. Res., 21, 1984-1990 (2012).

56) “Osiris Property Explorer.”: 〈http://www.organic-chemistry.org/ $\operatorname{prog} / \mathrm{peo} /$, cited 18 July, 2015

57) Ursu O, Rayan A, Goldblum A, Oprea T. Understanding druglikeness. WIREs Comput. Mol. Sci, 1, 760-781 (2011).

58) Kapetanovic IM. Computer-aided drug discovery and development (CADDD): in silico-chemico-biological approach. Chem. Biol. Interact., 171, 165-176 (2008).

59) The Practice of Medicinal Chemistry, Third Edition. (Wermuth CG ed.) Academic Press, San Diego (2008).

60) "PASS (Prediction of Activity Spectra for Substances) program.": 〈http://www.way2drug.com/passonline〉, cited 18 July, 2015.

61) Filimonov DA, Lagunin AA, Gloriozova TA, Rudik AV, Druzhilovskii DS, Pogodin PV, Poroikov VV. Prediction of the biological activity spectra of organic compounds using the pass online web resource. Chem. Heterocycl. Compd., 50, 444-457 (2014).

62) Filimonov DA, Poroikov V, Borodina Y, Gloriozova T. Chemical similarity assessment through multilevel neighborhoods of atoms:definition and comparison with the other descriptors. $J$. Chem. Inf. Comput. Sci., 39, 666-670 (1999).

63) Benaamane N, Nedjar-Kolli B, Bentarzi Y, Hammal L, Geronikaki A, Eleftheriou P, Lagunin A. Synthesis and in silico biological activity evaluation of new $N$-substituted pyrazolo-oxazin-2-one systems. Bioorg. Med. Chem., 16, 3059-3066 (2008).

64) Geronikaki A, Lagunin A, Poroikov V, Filimonov D, HadjpavlouLitina D, Vicini P. Computer aided prediction of biological activity spectra: evaluating versus known and predicting of new activities for thiazole derivatives. SAR QSAR Environ. Res., 13, 457-471 (2002).

65) Poroikov VV, Filimonov DA, Ihlenfeldt WD, Gloriozova TA, Lagunin AA, Borodina YV, Stepanchikova AV, Nicklaus MC. PASS biological activity spectrum predictions in the enhanced open NCI database browser. J. Chem. Inf. Comput. Sci., 43, 228-236 (2003). 66) Lagunin AA, Gomazkov OA, Filimonov DA, Gureeva TA, Di- 
lakyan EA, Kugaevskaya EV, Elisseeva YE, Solovyeva NI, Poroikov VV. Computer-aided selection of potential antihypertensive compounds with dual mechanism of action. J. Med. Chem., 46, 3326-3332 (2003).

67) Di Giorgio C, Delmas F, Filloux N, Robin M, Seferian L, Azas N, Gasquet M, Costa M, Timon-David P, Galy JP. In vitro activities of 7-substituted 9-chloro and 9-amino-2-methoxyacridines and their bis- and tetra-acridine complexes against Leishmania infantum. Antimicrob. Agents Chemother., 47, 174-180 (2003).
68) Geronikaki A, Babaev E, Dearden J, Dehaen W, Filimonov D, Galaeva I, Krajneva V, Lagunin A, Macaev F, Molodavkin G, Poroikov V, Pogrebnoi S, Saloutin V, Stepanchikova A, Stingaci E, Tkach N, Vlad L, Voronina T. Design, synthesis, computational and biological evaluation of new anxiolytics. Bioorg. Med. Chem., 12, 6559-6568 (2004).

69) Goel RK, Kumar V, Mahajan MP. Quinazolines revisited: search for novel anxiolytic and GABAergic agents. Bioorg. Med. Chem. Lett., 15, 2145-2148 (2005). 